UDK 618.39(4):347.158

342.7-055.2(4):173.4

Original scientific paper

\title{
ABORTION IN EUROPE
}

\author{
Ivana Tucak, PhD, Associate Professor \\ Josip Juraj Strossmayer University of Osijek, Faculty of Law \\ Stjepana Radića 13, Osijek, Croatia \\ itucak@pravos.hr
}

\author{
Anita Blagojević, PhD, Associate Professor \\ Josip Juraj Strossmayer University of Osijek, Faculty of Law \\ Stjepana Radića 13, Osijek, Croatia \\ ablagoje@pravos.hr
}

\begin{abstract}
There is a high level of agreement in the EU Member States with respect to a woman's right to abortion. Poland and Malta are the only exceptions to the liberal abortion regime in Europe. Yet, this issue is still considered highly divisive. The balance between a woman's right to abortion and the foetal right to life is still the topic of numerous legal and ethical discussions, which is a result of the recent rise of populism and anti-gender movements. In Europe, interwoven by different legal orders, international, supranational and national ones, the issue of human rights is dealt with at several levels. The EU Member States have assigned some of their sovereign rights to EU level, which is not the case with the area of reproductive rights and hence the issue of abortion is still firmly bound to state sovereignty.

The first part of the paper elaborates the issue of abortion within the framework of the Convention for the Protection of Human Rights and Fundamental Freedoms (hereinafter: ECHR) and EU law. Both the ECHR and the Charter of Fundamental Rights of the European Union grant every one the right to life whereas the protection of a woman's bodily integrity is set forth in Article 8 of the ECHR. Provisions on human rights are often featured by their general nature and it is up to judges to provide them with a more precise meaning. When it comes to international or supranational judicial bodies, such formulations might lead to controversial situations.
\end{abstract}

The second part of the paper sheds light on the recent case-law of the European Court of Human Rights and the Court of Justice. Both courts have been invited to examine the current regulation of abortion in the EU Member States. Furthermore, that part of the paper explores the most relevant decisions of the above courts with respect to the conflict between the foetal 
right to life and the woman's right to make autonomous decisions on her body and its influence on national abortion laws in the EU.

This is not the first paper that deals with this issue, so the third part of the paper investigates the relevant legal literature. What is challenged is the prevalent standpoint that the level of the protection of a woman's right to abortion is fairly low if judging by the case-law of the above courts since neither court has regarded a woman's right to abortion as a fundamental human right. The authors try to find an answer to the question whether abortion restrictions are contrary to the fundamental principle of gender equality.

Key words: abortion, Europe, supranational courts, Convention for the Protection of Human Rights and Fundamental Freedoms, Charter of Fundamental Rights of the European Union

\section{INTRODUCTION}

Contemporary Europe is characterized by the existence of "a multilevel system for the protection of human rights", in which national, supranational (EU) and international legal standards intertwine (Convention for the Protection of $\mathrm{Hu}$ man Rights and Fundamental Freedoms, hereinafter ECHR). ${ }^{1}$ The features of that multilevel constitutional regulation in the area of human rights ${ }^{2}$ include legal pluralism and heterarchy ${ }^{3}$ instead of legal monism and hierarchy. The issue of the influence of membership in the Council of Europe and European Union on a woman's right to access to a safe abortion has been gaining importance among legal scholars, primarily due to a growing number of cases handled by the European Court of Human Rights (hereinafter ECtHR) and the Court of Justice (hereinafter CJ) in this field in the last three decades. ${ }^{4}$ By the 1990s, abortion had been believed to fall outside the supranational level ${ }^{5}$ and there had been considerable differences in the approach to this issue between the Member States. ${ }^{6}$

As far as the European context is concerned, Fabbrini's paper The European Court of Human Rights, the EU Charter of Fundamental Rights and the right to abortion: Roe v. Wade on the other side of the Atlantic? deserves particular attention. Herein, his paper is both quoted and critically examined. According to him, although

Fabbrini, F., The European Court of Human Rights, the EU Charter of Fundamental Rights and the right to abortion: Roe $v$. Wade on the other side of the Atlantic? Columbia Journal of European Law, vol. 18, no. 1, 2011, p. 1. Fabbrini uses the term "multilevel constitutional architecture" to describe this system. Ibid., p. 5

$2 \quad$ Ibid., p. 5

3 Ibid., p. 6

$4 \quad$ Ibid., p. 2; 22; Fabbrini, F., The last holdout: Ireland, the right to abortion and the European federal human rights system (September 13, 2018), iCourts Working Paper Series, No. 142, 2018 [https://ssrn. com/abstract $=3249400]$, accessed 10. April 2020

5 Fabbrini, op. cit., note 4; Fabrini, op. cit., note 1, p. 34

$6 \quad$ Fabbrini, op. cit., note 1, p. 34 
abortion regulation is despite a noticeable transfer of sovereignty to international and supranational organizations still subject to national regimes, ${ }^{7}$ supranational law exerts pressure on the national legal systems of the Member States which impose strict restrictions on the access to abortion. ${ }^{8}$ The pressure has resulted in inconsistencies ${ }^{9}$ that have enticed particular Member States which did not adhere to "the supranational minima" 10 to amend their conditions for termination of pregnancy. ${ }^{11}$ Legal scholars conduct similar research within the framework of the United Nations. The impact of this organization on the liberalization of national abortion legislation is also significant. ${ }^{12}$

European courts define the scope of the human rights, the nature of which requires their formulation in a general way. ${ }^{13}$ The legislator or in case of international treaties, the drafting states shape "a vaguely worded provision", but it is up to judges to precisely establish its meaning. ${ }^{14}$ On such an occasion, the judges are obliged to provide proper reasoning. ${ }^{15}$ The position of European courts is in that light far more complex than that of national courts. The latter act within a national legal system while the former should take account of, when making respective decisions, both the European legislative framework and a national framework concerned. Due to the multilevel context of their action, European courts need to provide reasoning equally convincing to the applicants and referring Member States and on such an occasion, argumentation plays the decisive role. ${ }^{16}$

Currently there is no "broad individual right" to abortion on demand at European level. ${ }^{17}$ Hence, one needs to rely on precise legal terminology. Although it can often be heard that women should have the right to abortion, it needs to be noted that most states, when regulating abortion, do not regard that right as a right conceived by legal theoreticians or a right in its strict sense, implying a correlative

Ibid., p. 22

Ibid., p. 2

Ibid.

Fabbrini, op. cit., note 4

Fabbrini, op. cit., note 1, p. 3

Hunt, K.; Gruszczynski, M., The ratification of CEDAW and the liberalization of abortion laws, Politics \& Gender, vol. 15, no. 4, 2019, pp. 722-745; Zorzi, K., The impact of the United Nations on national abortion laws, Catholic University Law Review, vol. 65, no. 2, 2015, pp. 409-428

13 Senden, H., Interpretation of the Fundamental Rights in a Multilevel Legal System, Intersentia, 2011, p. 4

14 Ibid.

15 Ibid., p. 5

16 Ibid.

17 Fabbrini, op. cit., note 1, p. 3 
duty of the other side in a legal relation. ${ }^{18}$ In the context of abortion, women do not have absolute freedom to make choices. ${ }^{19}$

With respect to abortion, it is more convenient to speak about rights in the sense of liberties preventing all the other people in particular jurisdiction from, under the condition that all the requirements incorporated into the definition of this right have been met, contesting termination of pregnancy for being illegal. ${ }^{20}$ States prescribe conditions under which abortion can be performed legally, ${ }^{21}$ the deadline for its performance (generally in early stages of pregnancy) and similar. Likewise, it can be said that foetus has the "right to life" in the strict sense of the term right only if the women has a correlative duty to complete pregnancy. ${ }^{22}$

Most European states enforce liberal abortion laws, ${ }^{23}$ pursuant to which abortion can be performed upon request of a pregnant woman in an early stage of pregnancy. ${ }^{24}$ However, this issue remains controversial. A consensus on abortion is difficult to reach as one party to the conflict views abortion as murder while the other side views "it as a matter for the individual conscience". ${ }^{25}$

18 Scott, R., Risks, Reasons and Rights: The European Convention on Human Rights and English Abortion Law, Medical Law Review, vol. 24, no. 1, 2015, pp. 1-2

19 Ibid., pp. 1-2

20 Flathman, R., Toward a liberalism, Cornell University Press, Ithaca, London, 1989, p. 173

21 Scott, op. cit., note 18 , p. 2

22 Dixon, R.; Nussbaum, M. C., Abortion, dignity, and a capabilities approach, in: Baines, B.; D. Barak-Erez, D.; Kahana, T. (eds.), Feminist constitutionalism: Global perspectives, Cambridge University Press, 2012, p. 71

23 Fabbrini, op. cit., note 1, p. 8.

24 Ibid.

Pursuant to the petition submitted to the Croatian Constitutional Court by the CESI - Centre for Education, Counselling and Research in the procedure for assessing the conformity of the Act on Health Measures for the Realization of the Right to Freely Decide on the Childbirth (Official Gazette no. 18/78.) with the Constitution of the Republic of Croatia, 22 countries (Austria, Bosnia and Herzegovina, Bulgaria, Czech Republic, Denmark, Estonia, France, Greece, Croatia, Latvia, Lithuania, Luxembourg, North Macedonia, Germany, Norway, Portugal, Rumania, Serbia, Slovakia, Slovenia, Spain and Sweden) do not require women to reveal their reasons for an abortion. Unlike them, three states (Belgium, the Netherlands and Rumania) require women to lay down their unfavourable living conditions as reasons for an abortion, one state (Italy) prescribes reference to unfavourable social, economic or family circumstances and one state (Hungary) obliges women to indicate their state of a severe crisis.

CESI - Centre for Education, Counselling and Research, Expert opinion to the Constitutional Court of the Republic of Croatia in reviewing the constitutionality of the Act on Health Measures for the Realization of the Right to Freely Decide on the Childbirth (Official Gazette no. 18/78), [http://stari. cesi.hr/attach/_e/expert_opinion_cc-5.pdf], accessed 01. February 2019

25 Williams, G., The Fetus and the "Right to Life" The Cambridge Law Journal, vol. 53, no, 1, 1994, p. 74 
By the 1960s, abortion had been prohibited in most states. In Europe, legal rules kept track with religious ones for long ${ }^{26}$ since abortion was contrary to the Christian beliefs on the sanctity of life. ${ }^{27}$ Abortion was also deemed contrary to the fundamental principles of the medical profession. For instance, the Hippocratic Oath includes the following maxim: "I will not give a woman a pessary to cause an abortion". ${ }^{28}$ Criminal law started regulating abortion in the $19^{\text {th }}$ century. ${ }^{29}$ Apart from the sanctity of life, prohibition of abortion resulted, as asserted by Williams, from the fact that abortion was an extremely risky medical intervention..$^{30}$ Indeed, the legislation of the $19^{\text {th }}$ century was aimed, among other things, at protection of a woman's health and life. The advancement of medicine has diverted attention from the above medical reasons ${ }^{31}$ to the protection of traditional moral values. ${ }^{32}$

The article is divided into three main parts. The first part of the paper elaborates the issue of abortion within the framework of the ECHR and EU law. The second part of the paper sheds light on the recent case-law of the ECtHR and the CJ. Both courts have been invited to examine the current regulation of abortion in the EU Member States. This is not the first paper that deals with this issue, so the third part of the paper investigates the relevant legal literature. What is challenged is the prevalent standpoint that the level of the protection of a woman's right to abortion is fairly low if judging by the case-law of the above courts since neither court has regarded a woman's right to abortion as a fundamental human right. The authors try to find an answer to the question whether abortion restrictions are contrary to the fundamental principle of gender equality. We will conclude with some thoughts on the challenges that lie ahead. The paper utilizes descriptive, comparative and method of analysis.

\section{DOES FOETUS HAVE A RIGHT TO LIFE?}

The discussion on the begging of "human personhood" has a long history. ${ }^{33}$ This issue arouse great interest of the philosophers who explore the moral status of

28 The Hippocratic Oath, Translated by Michael North, National Library of Medicine, 2002, [https:// www.nlm.nih.gov/hmd/greek/greek_oath.html], accessed 10. January 2020. Although, as Williams points out, Hippocrates's position is not coherent. He considered abortion permissible in the case of slave prostitutes. Williams, op. cit., note 25 , p. 72

29 Fabbrini, op. cit., note 1, p. 9

30 Williams, op. cit., note 25, p.72

$31 \quad$ Ibid., p. 72

32 Fabbrini, op. cit., note 1, p. 9

33 See Williams, op. cit., note 25, p. 71
} 
foetus and its possible difference from the status of a child. ${ }^{34}$ For philosophers, this discussion is closely related to the issue of the meaning of the term of human life. ${ }^{35}$ In the legal sense, this discussion intensified in the 1970s when states began to liberalize abortion laws and it came to the issue of the conformity of abortion with the constitution, which appeared in various cases handled by national or supreme courts. In the 1990s, such cases were no exception at the ECtHR and CJ either. ${ }^{36}$

Today the opponents of abortion mostly present their reasons in a secular way and their assertions are based on human rights and on the foetal right to life, and not on religious assumptions on the sanctity of life. ${ }^{37}$ A subtle approach to this issue in contemporary states in which religion is separated from the state can be regarded as respect for the constitution, holds Williams, and thus the opponents of abortion can get support of non-religious person too. ${ }^{38}$ Utilization of human rights is omnipresent nowadays. ${ }^{39}$ Human rights represent the lingua franca of the contemporary pluralist world. ${ }^{40}$ In this section of the paper, we will provide an overview of the constitutional provisions on the right to life, i.e. of the provisions of the most relevant European legal instruments containing it.

In doing so, we most frequently come across expressions like "everyone has the right to life" and "the right to life is guaranteed to every human being", without defining the terms "everyone" and "human being", and generally, but not completely, without explicitly stating a special right to life before birth. Very few states recognise in their constitutions - explicitly or implicitly - a special right to life before birth. In European countries, the right to life of the unborn was explicitly recognised by the constitution only in the Republic of Ireland.

Irish abortion laws have always been strict. Abortion was first considered a misdemeanour according to common $\operatorname{law}^{41}$ and then it was prohibited pursuant to Section 58 of the Offences against the Person Act 1861, ${ }^{42}$ which envisaged life imprisonment for both the pregnant woman and the doctor who performed the

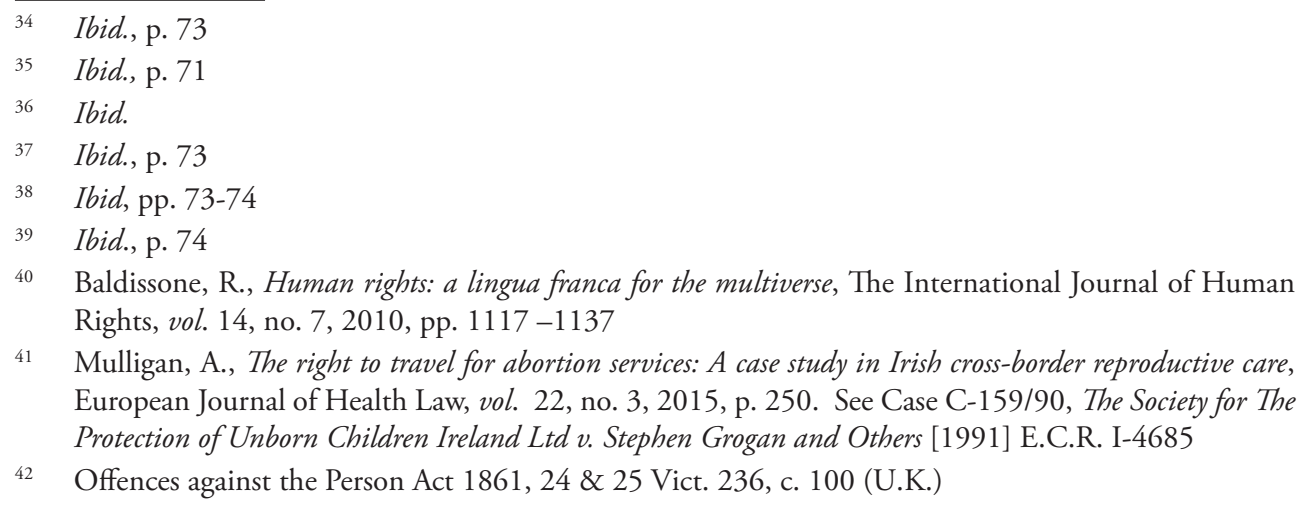

41 Mulligan, A., The right to travel for abortion services: A case study in Irish cross-border reproductive care, European Journal of Health Law, vol. 22, no. 3, 2015, p. 250. See Case C-159/90, The Society for The Protection of Unborn Children Ireland Ltd v. Stephen Grogan and Others [1991] E.C.R. I-4685

42 Offences against the Person Act 1861, 24 \& 25 Vict. 236, c. 100 (U.K.) 
abortion. ${ }^{43}$ The 1979 Health (Family Planning) Act embraced the formulation of the stated $19^{\text {th }}$ century Act. ${ }^{44}$ Based on the results of the 1983 referendum, the Irish Constitution was amended or more precisely, the Eight Amendment of the Constitution of Ireland established the right of the unborn to life with the same appreciation for foetus as for the life of mothers (Article 40.3.3 of the Constitution of Ireland). ${ }^{45}$ Since the Eight Amendment, there have been a number of referring lawsuits, including litigation before the CJ and ECtHR. ${ }^{46}$ The whole situation resulted in the adoption of two amendments to the Constitution of Ireland. The Thirteenth Amendment permitted women to travel outside Ireland to have their pregnancy terminated ${ }^{47}$ and the Fourteenth Amendment introduced "the right to provide information about abortion services performed overseas". ${ }^{48}$ Ultimately, it should be noted that in the referendum held in May 2018, an overwhelming majority of the Irish people voted to remove this amendment from the Constitution. ${ }^{49}$ The Eighth Amendment has been substituted with a provision permitting the Irish Parliament (Oireachtas) to legally regulate the issue of abortion. ${ }^{50}$ Thus, Poland and Malta became the member states of the European Union with the strictest abortion legislation. In terms of the rigidity of its post-communist abortion regime, Poland permits abortion only in three exceptional cases. ${ }^{51} \mathrm{~A}$ failure to comply with the respective restrictions in this view may bring to 3-year

43 Offences Against the Person Act 1861, $\$ \$ 58,59$. According to Mulligan, op. cit., note 41, pp. 250-1, note 48; Fabbrini, op. cit., note 1, pp. 18-9

44 Health (Family Planning) Act 1979 (Act No. 20/1979), $\$ 10$ (Ir.). According to Mulligan, op. cit., note 41, pp. 250-1, note 48; Fabbrini, op. cit., note 1, p. 18-19

45 Fabbrini, op. cit., note 1, p. 19; Mulligan, op. cit., note 41, p. 252

46 Fabbrini, op. cit., note 1, pp. 19-20

47 IR. CONST., 1937, art. 40.3.3 (2), as amended by the Thirteenth Am. (1992). According to Fabbrini, op. cit., note 1, p. 20; Mulligan, op. cit., note 41, p. 254

48 IR. CONST., 1937, art. 40.3.3(3), as amended by the Fourteenth Am. (1992). According to Fabbrini, op. cit., note 1, p. 20; Mulligan, op. cit., note 41, p. 255

Prior to the approval of the Maastricht Treaty (1992), Ireland fought for an additional protocol stating that the Treaty would not affect the application of the Irish constitutional provision on abortion. Protocol Annexed to the Treaty on European Union and to the Treaties Establishing the European Communities, Feb. 7, 1992, 1992 O.J. (C 224/130). According to Fabbrini, op. cit., note 1, p. 26

49 In the 2018 referendum, the Irish electorate voted by 1,429,981 (66.4\%) votes to $723,632(33.6 \%)$ in favour of removing the Eighth Amendment from the Constitution. The turnout nationally was $64.13 \%$. Vedran Brkulj, Za legalizaciju pobačaja u Irskoj glasalo je 66.4 posto građana, [https://www.tportal.hr/vijesti/clanak/za-legalizaciju-pobacaja-u-irskoj-glasalo-je-66-4-posto-gradana-foto-20180526], accessed 31. January 2019

50 Constitution of the Republic of Ireland [http://www.irishstatutebook.ie/eli/cons/en\#article40], accessed 31. January 2020

51 According to the Act on Family-Planning, Human Embryo Protection and Conditions of Legal Pregnancy Termination, Jan. 7, 1993, par. 4(a), abortion is permitted in three exceptional cases:

"(1) a physician, other than the one which performs the abortion, certifies that the pregnancy is endangering the mother's life or health; (2) up to viability (i.e., up to the twenty-fourth week), if the fetus 
imprisonment. ${ }^{52}$ Malta is the only EU Member State where abortion is completely banned even if pregnancy represents a risk to the pregnant woman's life. ${ }^{53}$

Three East European constitutions (i.e. Hungarian, $\mathrm{Czech}^{54}$ and Slovak ${ }^{55}$ ) contain provisions relating to pre-birth child protection, that is, stipulating that human life deserves to be protected before birth. However, the constitutional courts of these states have interpreted these provisions such that they do not recognise a special right to life of the unborn, but a constitutional value that enjoys special protection of the state. ${ }^{56}$ In this context, the Hungarian example is instructive. While the Czech and Slovakian Constitution emerged in 1992, the Hungarian Constitution was adopted in January 2010. Article II of the Hungarian Constitution stipulates as follows:

is seriously impaired; or (3) up to the twelfth week, if pregnancy resulted from rape“. According to Fabbrini, op. cit., note 1, pp. 17-18

52 Fabbrini, op. cit., note 1, p. 18

53 Gravino, G.; Caruana-Finkel, L., Abortion and methods of reproductive planning: the views of Malta's medical doctor cohort, Sexual and Reproductive Health Matters, vol. 27, no. 1, 2019, p. 288

54 Pursuant to Article 6 of the Charter of Fundamental Rights and Freedoms of the Czech Republic, which is part of the constitutional order of the Czech Republic, everybody has the right to life, and human life deserves to be protected even before birth

Charter of Fundamental Rights and Freedoms - Resolution of the Presidium of the Czech National Council of 16 December 1992 on the Declaration of the Charter of Fundamental Rights and Freedoms as a part of the constitutional order of the Czech Republic, [https://www.usoud.cz/fileadmin/ user_upload/ustavni_soud_www/Pravni_uprava/AJ/Listina_English_version.pdf], accessed 30. January 2019

55 Pursuant to Article 15 (1) of the Constitution of the Slovak Republic, everyone has the right to life and human life deserves to be protected even before birth. This provision is identical to the previously mentioned provision of the Czech Charter of Fundamental Rights and Freedoms. Constitution of the Slovak Republic [https://www.prezident.sk/upload-files/46422.pdf], accessed 30. January 2019

56 Ruling of the Constitutional Court of the Republic of Croatia no. U-I-60/1991 et al. of 21 February 2017 and the dissenting opinion (Rješenje Ustavnog suda Republike Hrvatske, broj: U-I-60/1991. i dr. od 21. veljače 2017. i izdvojeno mišljenje), Official Gazette, No. 25/17, par. 31, [https://sljeme.usud.hr/ usud/praksaw.nsf/7114c25caa361e3ac1257f340032f11e/c12570d30061ce54c12580d100416faf/\$FILE/U-I-60-1991\%20i\%20dr.pdf], accessed 30. January 2020. Unofficial abridged translation into English: [https://www.law.utoronto.ca/utfl_file/count/documents/reprohealth/croatia_2017_constitutional.pdf], accessed 30. January 2020. See: Finding of the Constitutional Court of the Slovak Republic, Ref. No. I. ÚS 12/01 of 4 December 2007, published in the Collection of Laws of the Slovak Republic under no. 14/2008, volume 8, [https://www.ustavnysud.sk/documents/10182/992296/1_07a. pdf/88e635ba-300a-4cf3-a71b-99ecfe2c8e54], accessed 30. January 2020. Constitutional Court of Hungary, Decision 64/1991 on the Regulation of Abortion, [https://hunconcourt.hu/dontes/decision-64-1991-on-the-regulation-of-abortion], accessed 30 January 2020 
"Human dignity shall be inviolable. Every human being shall have the right to life and human dignity; the life of the foetus shall be protected from the moment of conception." ${ }^{57}$

In the same year, the Hungarian Parliament adopted a new Family Protection Act which protects foetus from the moment of conception. The abortion regime thus became stricter since it included mandatory counselling consisting of two meetings which shall be three days apart. These are indicators of the conservative trend in Hungary where the Fidesz and Christian Democratic Party (KDNP) coalition has held power since $2010 . .^{58}$

With respect of evaluation of the above constitutional provisions, it should be stressed that law requires "precise language" and in the legal context, the term "unborn child" cannot be identified with the term "child" ${ }^{59}$ Those constitutional texts do not use scientific terminology either. They do not involve terms like embryo or foetus. ${ }^{60}$

The Croatian Constitution does not explicitly recognise the right to life before childbirth. ${ }^{61}$ Article 21 (1) thereof governs that "Each human being has the right to life." It is interesting that its predecessor, the 1974 Constitution of the Socialist Federal Republic of Yugoslavia, or more precisely its Article 272 used the following formulation:

"It is man's right to freely decide on childbirth.

This right can be restrained only for the sake of man's health.”

There is no such explicit provision in the applicable Croatian Constitution. On the other hand, although the Basic Law for the Federal Republic of Germany does not contain any provisions on life before birth, the German Federal Constitutional Court has interpreted the term "everyone" given in Article 2(2) of the Basic Law (i.e. "Everyone has the right to life and bodily integrity.") as a constitutional

57 The Fundamental Law of Hungary, English translation of consolidated version [http://www.kormany. hu/download/f/3e/61000/TheFundamentalLawofHungary_20180629_FIN.pdf], accessed 30. January 2020

58 Vida, B., New waves of anti-sexual and reproductive health and rights strategies in the European Union: the anti-gender discourse in Hungary, Sexual and Reproductive Health Matters, vol. 27, no. 2, 2019, p. 14

59 Williams, op. cit., note 25, p. 73

${ }_{60}$ Mulligan, op. cit., note 41, p. 252

${ }_{61}$ The Constitution of the Republic of Croatia (Ustav Republike Hrvatske), Official Gazette, No. 56/90, $135 / 97,8 / 98,113 / 00,124 / 00,41 / 01,55 / 01,76 / 10$ and $5 / 14$ 
provision that also protects "the life developing in the mother's womb" as "an independent legal value". ${ }^{62}$

As a fundamental human right, the right to life is guaranteed by a number of international instruments adopted (primarily) by the United Nations and the Council of Europe. In the context of the Council of Europe, the basic document for the protection of human rights adopted by this organisation is the ECHR (1950), ${ }^{63}$ whose creators also used the expression "everyone". Pursuant to Article 2 (1): "Everyone's right to life shall be protected by law".

The creators of the ECHR did not discuss the right to life before birth at all. ${ }^{64}$ At the time of the ECHR preparation, criminal law prohibited abortion in all contracting parties. ${ }^{65}$ In what follows, we will see that neither (first) the European Commission of Human Rights nor (subsequently) the ECtHR have found in their case law that the foetus falls under the term "everyone" within the meaning of Article 2 of the ECHR.

It is also necessary to mention the relevant provisions of the Convention on the Protection of Human Rights and the Dignity of the Human Being with regard to the Application of Biology and Medicine: the Convention on Human Rights and Biomedicine (1997). ${ }^{66}$ Pursuant to Article 1:

"Parties to this Convention shall protect the dignity and identity of all human beings and guarantee everyone, without discrimination, respect for their integrity and other rights and fundamental freedoms with regard to the application of biology and medicine."

The latter Convention is the only legally binding international instrument that regulates both the issue of human rights and the issue of biomedicine (bioethics). It is evident that even in this instrument, there is no definition of a human being. Instead, the Convention applies the term "everyone", accompanied with no defi-

62 Decision of the German Federal Constitutional Court, BVerfGE 39, 1 c (Schwangerschaftsabbruch I), cited in the Ruling of the Constitutional Court of the Republic of Croatia, p. 50

63 Convention for the Protection of Human Rights and Fundamental Freedoms, as amended by Protocol No. 14 to the Convention, Official Gazette - International Treaties, Nos. 18/97, 6/99 - consolidated text, 8/99 - correction

64 Copelon, R.; Zampas, C.; Brusie, E.; de Vore, J., Human rights begin at birth: international law and the claim of fetal rights, Reproductive Health Matters, vol. 13, no. 26, 2005, p. 123

65 Fabbrini, op. cit., note 1, p. 27

66 Convention on the Protection of Human Rights and the Dignity of the Human Being with regard to the Application of Biology and Medicine: the Convention on Human Rights and Biomedicine, Official Gazette - International Treaties, Nos. 13/03, 18/03 and 3/06 
nition. ${ }^{67}$ The Explanatory Report to the Convention emphasizes that due to a lack of a consensus on the definition of this notion among the contracting states, their national legislation should provide for clarification what is meant under a human being. ${ }^{68}$ However, it should be noted that the Convention on Human Rights and Biomedicine does contain provisions on "the prenatal phase", particularly in its Chapter IV - Human Genome. ${ }^{69}$ Furthermore, the ECtHR refers to this Convention in its case-law and one of its most interesting cases concerning this paper is the case of Vo v. France where the ECtHR had referred to this Convention even before France ratified it. ${ }^{70}$

It seems that the relevant conclusions of Council of Europe Parliamentary Assembly Resolution 1607 (2008) - "Access to safe and legal abortion in Europe" (2008) should be accentuated in this context as well despite their legally non-binding character. ${ }^{71}$ In these conclusions, the Parliamentary "Assembly takes the view that abortion should not be banned within reasonable gestational limits", and that "a ban on abortion does not result in fewer abortions but mainly leads to" illegal abortions, that result in a number of adverse effects, such as increased maternal mortality, "abortion tourism", and social inequalities (conclusion 4).

The viewpoint that strict abortion laws have no impact on abortion rates is supported by numerous empirical studies. For example, Stašević and Ropac found in 2018 that states with a liberal abortion regime are featured by an abortion incidence of 34/1000 whereas states with numerous abortion restrictions, where abortion can be performed only in the event of a threat to the mother's life, have somewhat higher abortion incidence (37/1000). ${ }^{72}$ A lack of access to a safe and lawful abortion threatens a woman's fundamental right to life, not just her social,

67 Judgement Vo v. France (2004) 40 EHRR 12, par. 84

$68 \mathrm{Ibid}$., para 84. This also applies to the Additional Protocol on the Prohibition of Cloning Human Beings and the Additional Protocol on Biomedical Research. Nys, H., Towards an international treaty on human rights and biomedicine? Some reflections inspired by UNESCO's Universal Declaration on Bioethics and Human Rights, European Journal of Health Law, vol. 13, no. 1, pp. 7-8

${ }^{6}$ Vo v. France. Dissenting opinion of judge Mularoni joined by judge Stražnicka

70 Nys, op. cit., note 68, pp. 7-8. France ratified this Convention on 13 December 2011 Committee on Bioethics, Chart of signatures and ratifications of the Convention on Human Rights and Biomedicine, Strasbourg, 17 May 2019, [https://rm.coe.int/inf-2019-2-etat-sign-ratif-reservesbil-002-/16809979a8], accessed 20. April 2020

71 Resolution 1607 (2008) - Access to safe and legal abortion in Europe, [http://assembly.coe.int/nw/ xml/XRef/Xref-XML2HTML-en.asp?fileid=17638], accessed 20. April 2020

72 Stašević, I.; Ropac, D., Statistički podaci o pobačajima u Hrvatskoj - neke osobitosti i usporedbe, Društvena istraživanja, vol. 27 , no. 2, 2018, p. 347 
health and private interests. It is estimated that 68,000 women die annually as a consequence of an illegal abortion. ${ }^{73}$

Finally, an important document of the European Union - Charter of Fundamental Rights of the European Union (hereinafter CFR, 2010), also contains a relevant provision on the right to life. Pursuant to Article 2 (1): "Everyone has the right to life." As can be seen, the creators of the CFR also opted for a general expression "everyone" without defining the scope of this term. On 1 December 2000, when the Treaty of Lisbon Amending the Treaty on European Union and the Treaty Establishing the European Community (hereinafter Lisbon Treaty) ${ }^{74}$ entered into force, the CFR became legally binding according to its Article 6 (1) or in other words, it obtained the status of a treaty. ${ }^{75}$

\section{CASE LAW OF THE EUROPEAN COURTS}

Although a very sensitive subject, contemporary case law of the ECtHR in relation to the right to life and termination of pregnancy is relatively rich. On the other hand, the case law of the CJ on this matter is not so extensive. However, to date, neither of the two European courts has provided an affirmative answer to the question as to whether an unborn person can be considered a person in the sense of exercising the right to life.

\subsection{Abortion and the European Court of Human Rights}

The case-law of the ECtHR with regard to the obligations arising from the right to life has significantly evolved over the last thirty years. In doing so, the issues related to unborn humans have so far been largely examined by the ECtHR in the light of "life" as provided for in Article 2(1) and "private and family life" as provided for in Article 8 of the ECHR, and recently, within the framework of two cases initiated based on applications against Poland and appertaining violation of Article 3 prohibiting torture and inhuman or degrading treatment or punishment. When exploring the case-law of the ECtHR, it should be highlighted that until the enactment of the $11^{\text {th }}$ additional Protocol to the ECHR, individual applications had been first considered by the European Human Rights Commission. ${ }^{76}$ Since the case-law of the ECtHR in regard to abortion mostly refers to violation

\footnotetext{
73 Hunt; Gruszczynski, op. cit., note 12, pp. 730-1

74 Treaty of Lisbon Amending the Treaty on European Union and the Treaty Establishing the European Community, Dec. 3, 2007, 2007 O.J. (C 306) 30

75 Fabbrini, op. cit., note 1, pp. 6, 7, 61

76 Fabbrini, op. cit., note 1, p. 27
} 
of Article 8 of the ECHR, which stipulates respect for private and family life, the following lines deal with the scope of this Article.

\subsubsection{Right to respect for private and family life}

Article 8 of the ECHR provides a broad notion of private life. The ECtHR has established that the protection of private life, laid down in Article 8:

"encompasses, inter alia, the right to personal autonomy and personal development (...). This concerns subjects such as gender identification, sexual orientation and sexual life (...), a person's physical and psychological integrity (..) as well as decisions both to have and not to have a child or to become genetic parents". ${ }^{77}$

Article 8 envisages positive and negative obligations of the contracting states. ${ }^{78}$ In terms of negative ones, ${ }^{79}$ the ECtHR conducts triple analysis. ${ }^{80}$ In order to be eligible, interference shall be "in accordance with the law", shall result from "the legitimate aims" depicted in Article 8 (2) of the ECHR and shall be "necessary in a democratic society" ${ }^{81}$ When performing such analysis, the ECtHR regularly finds that the sued state has meet the first two requirements without thoroughly analysing them. It focuses on the third requirement and seek whether the interference was "necessary in a democratic society" or not. ${ }^{82}$ "Necessity" is the most delicate requirement for qualifying interference as acceptable. ${ }^{83}$

In order to be "in accordance with the law", interference shall be based on national law which needs to be "adequately accessible" and tailored "with sufficient precision to enable the citizen to regulate his/her conduct". ${ }^{84}$ In compliance with Article 8 (2) of the ECHR, interference has a legitimate aim if it supports national

\footnotetext{
77 Judgement $A$., B. and C v. Ireland (2011) 53 E.H.R.R 13, par. 212

78 Fenwick, D., The Modern abortion jurisprudence under Article 8 of the European Convention on Human Rights, Medical Law International, vol. 12, no. 3-4, 2013, p. 251

79 Scott, op. cit., note 18, p.7.

In Tysiac v. Poland, the ECtHR laid down fundamental principles with regard to Article 8.

Judgement Tysiac v. Poland (2007) 45 EHRR 42, par. 109. For more detail, see Scott, op. cit., note 18, p.7.

80 Scott, op. cit., note 18, p. 7

81 Tysiac v. Poland, par. 109. See also A., B. and C. v. Ireland, par. 218; Fabbrini, op. cit., note 1, pp. 54-55

82 Weinstein, B., Reproductive choice in the hands of the state: The right to abortion under the European Convention on Human Rights in light of $A, B$ \& $C v$. Ireland, American University International Law Review, vol. 27, no. 2, 2012, p. 402. Weinstein paraphrases Letsas, G., A Theory of Interpretation of the European Convention on Human Rights, Oxford University Press, 2009

$83 \quad$ Ibid, p. 402

${ }^{84}$ A., B. and C. v. Ireland, par. 220
} 
security, public safety, the economic well-being, crime prevention, protection of health, morals or the rights and freedoms of others. According to well-established case law of the ECtHR, the necessity element "implies that the interference corresponds to a pressing social need and in particular that it is proportionate to one of the legitimate aims pursued by the authorities". ${ }^{85}$

On the other hand, "positive obligations inherent in an effective 'respect' for private life" 86 can encompass:

"adoption of measures designed to secure respect for private life even in the sphere of relations between individuals, including both the provision on a regulatory framework of adjudicatory and enforcement machinery protecting individuals' rights and implementation, where appropriate, of specific measures" ${ }^{87}$

For example, they may involve the obligation of a contracting state to amend its regulations in a way that a particular medical intervention is made available to people in need.$^{88}$ It may come to violation of Article 8 of the ECHR if a contracting stare fails, without a reasonable justification, to design an appropriate legal framework for autonomy in the private dimension of life. ${ }^{89}$ The ECHR shall "guarantee not rights that are theoretical or illusory but rights that are practical and effective." ${ }^{\prime 0}$ Let us mention that positive and negative obligations of the contracting states cannot be precisely defined and that the applicable principles are similar in both cases. ${ }^{91}$

"In both the negative and positive contexts, regard must be had to the fair balance that has to be struck between the competing interests of the individual and of the community as a whole; and in both contexts, the State enjoys a certain margin of appreciation". ${ }^{92}$

The margin of appreciation of the ECtHR resembles that of "the U.S. Supreme Court on the occasion of determining the proper level of scrutiny to apply when deciding if a state law is unconstitutional." The Supreme Court defines this margin depending on the nature and scope of a particular right. In European law, "a nar-

Tysiac v. Poland, par. 109; See also Scott, op. cit., note 18, p. 7

Tysiac v. Poland, par. 110; See also Fenwick, op. cit., note 78, pp. 261-266

Tysią v. Poland, par. 110. See also Scott, op. cit., note 18, p. 7

Fenwick, op. cit., note 78, p. 251

Ibid.

Tysiac v. Poland, par. 113; A., B. and C. v. Ireland, par. 267; See also Scott, op. cit., note 18, p. 8

Tysiąc v. Poland, par. 111. See also Scott, op. cit., note 18, p. 7

Tysiac v. Poland, par. 111 
row margin of appreciation" corresponds to "the U.S. Supreme Court's strict scrutiny standard" and "a wide margin of appreciation" to "the rational basis test". ${ }^{93}$

The ECtHR has observed that considering positive obligations of the contracting states, the term "respect" is vague and that due to different national practices, applications differ considerably from each other. ${ }^{94}$ When assessing positive obligations of a state, its "rule of law" should be scrutinized since this concept is connected with every article of the ECHR. ${ }^{95}$

\subsubsection{Case-law of the European Court of Human Rights}

The first consideration of the question whether the right to life from Article 2 of the ECHR extends to foetal life was given by the European Commission on $\mathrm{Hu}$ man Rights in 1980 in the Paton v. United Kingdom case (sometimes cited as X. v. United Kingdom). ${ }^{96}$ In this case the Commission considered the terms "everyone" and "life" in the context of the ECHR (especially its Article 2) and stated explicitly that the context in which the term "everyone" is employed "does not include the unborn" child. ${ }^{97}$ Furthermore, when considering the relation between the right to "life" of the foetus and the right to life of the pregnant woman, the Commission reached the following conclusion:

"The life of the foetus is intimately connected with, and it cannot be regarded in isolation of, the life of the pregnant woman. If Article 2 were held to cover the foetus and its protection were, in the absence of any express limitation, seen as absolute, an abortion would have to be considered as prohibited even where the continuance of the pregnancy would involve a serious risk to the life of the pregnant woman. This would mean that the 'unborn life' of the foetus would be regarded as being of a higher value than the life of the pregnant woman." ${ }^{8}$

This position was supported by the Commission twelve years later (1992) in the case H. v. Norway, ${ }^{99}$ as well as by the ECtHR ten years later (2002) in the case

\footnotetext{
93 Weinstein, op. cit., note 82, pp. 402-3

${ }_{94}$ Tysiac v. Poland, par. 112; See also Scott, op. cit., note 18, p. 8

95 Ibid.

96 Judgement Paton v. United Kingdom (1981) 3 EHRR 408 [https://www.globalhealthrights.org/ wp-content/uploads/2013/10/EComHR-1980-Paton-v.-United-Kingdom-X.-v.-United-Kingdom. pdf]

97 Ibid., par. 9; CESI, op. cit., note 24, p. 5

98 Ibid., par. 9; CESI, op. cit., note 24, p. 5

99 Judgement H. v. Norway (1992) 73 DR 155; CESI, op. cit., note 24, p. 5
} 
Boso v. Italy. ${ }^{100}$ It can be noticed that in all three cases the competent authority provided justification for the disputed national acts and rejected the claims lodged by applicants (potential fathers) on the grounds that the states shall have a wide margin of appreciation of this sensitive issue. ${ }^{101}$

In the case of Vo v. France (2004), ${ }^{102}$ which concerns a pregnant female patient who underwent a therapeutic abortion due to medical negligence, the ECtHR consolidated the existing case-law on the right to life and termination of pregnancy and conducted (until then) the most thorough examination of the right to life of the unborn human. ${ }^{103} \mathrm{On}$ the basis of a review of case law up to that date, the ECtHR affirmed again that "the unborn child is not regarded as a 'person' directly protected by Article 2 of the ECHR and that if the unborn do have a 'right' to 'life', it is implicitly limited by the mother's rights and interests", noting that this does not mean that the ECHR authorities eliminated "the possibility" that under special circumstances protection could also "be extended to the unborn". ${ }^{104}$

The ECtHR finally concluded that the contracting states enjoy a margin of appreciation when it comes to the beginning of life. ${ }^{105}$ It drew that conclusion irrespective of the fact that the ECHR is "a living instrument" which should be interpreted in line with current conditions ("an evaluative interpretation of the Convention"). ${ }^{106}$ The ECtHR reiterated that among member states "there is no consensus on the nature and status of the embryo" or foetus, although it can be seen that "they are beginning to receive some protection", primarily "in the light of scientific progress"- e.g. genetic engineering, medically assisted procreation and embryo experimentation. ${ }^{107}$

Senden mentions this case as a good example of comparative interpretation applied by the ECtHR for the sake of backing the viewpoint that "the issue is not ripe for the interpretation by the Court". ${ }^{108}$ As to ascertain whether the term "everyone" stated in Article 2 of the ECHR comprises foetus, the ECtHR took

\footnotetext{
100 Judgement Boso v. Italy (2002), App. No. 50490/99, Eur. Ct. H.R. 846; CESI, op. cit., note 24, p. 5

101 "The Commission finds that in such a delicate area the Contracting States must have a certain discretion." H. against Norway, par. 1; CESI, op. cit., note 24, p. 5

102 Vo v. France; CESI, op. cit., note 24, p. 5. The applicant was pregnant and attended a hospital for a medical check-up, where she was mistaken for another woman and had an IUD placed inside the uterus, which caused the loss of amniotic fluid, and ultimately the foetal death

103 Ruling of the Constitutional Court of the Republic of Croatia, par. 15

104 Vo v. France, par. 80

105 Ibid., par. 82

106 Ibid.

107 Ibid., par. 84

108 Senden, $o p$. cit., note 13, p. 233
} 
advantage of comparative interpretation and concluded that there is neither a legal nor a scientific consensus on the issue when life begins. The only ground common to all contracting states relates to the fact that foetus or embryo belongs to human race. ${ }^{109}$ Senden emphasizes that the ECtHR used a margin of appreciation "in the interpretation phase" of this case, which is unusual, since this doctrine is in principle used "in the phase of application" when "justifying the interference". ${ }^{110}$ Moreover, holds Senden, the ECtHR wanted to put emphasis on the lack of a consensus among contracting parties, which is not always the case. ${ }^{111}$ The ECtHR concluded that:

"the potentiality of that being and its capacity to become a person require (...) protection in the name of human dignity, without making it a 'person' with the 'right to life' for the purposes of Article 2". ${ }^{112}$

In view of the aforementioned, the ECtHR found that "it is neither desirable, nor even possible" to provide an abstract answer to the question whether the unborn is a person within the meaning of Article 2 of the ECHR. ${ }^{113}$ The notion of human dignity appears here as a substitute for reference to human rights as human rights are possessed only by living people whereas dignity belongs to all mankind as such and foetus is undoubtedly part thereof. ${ }^{114}$

The ECtHR has not changed its legal views in any of its recent judgments related primarily to Article 8 of the ECHR. In the case of A., B. and C. v. Ireland (2011), which was initiated by three applicants, two Irish citizens and one Lithuanian citizen with residence in Ireland who had to travel outside Ireland in order to procure a safe abortion. ${ }^{115}$ At that time, Ireland was still characterized by one of the most rigorous abortion regime in Europe. ${ }^{116}$

All the applicants complained about violation of Article 8 of the ECHR in regard to abortion prohibition. The first two applicants complained about the unavail-

\footnotetext{
109 Ibid., p. 233. Vo v. France, par. 84

110 Senden, op. cit., note 13, p. 234

111 Ibid. Senden mentions the Judgement Kimlya and Others $v$. Russia (2009), App. No. 76836/01 and $32782 / 03$

112 Vo v. France, par. 84

113 Ibid., para 85

114 Andorno, R., Human dignity and human rights as a common ground for a global bioethics, The Journal of Medicine and Philosophy: A Forum for Bioethics and Philosophy of Medicine, vol. 34, no. 3, 2009, p. 228

115 See Fabbrini, op. cit., note 1, pp. 49-50

116 Fabbrini, op. cit., note 1, p. 4; Fenwick, D., "Abortion Jurisprudence” at Strasbourg: Deferential, Avoidant and Normatively Neutral? Legal Studies, vol. 34, no. 2, 2014, p. 217
} 
ability of abortion "for health and well-being reasons" whereas the third one was not able to exercise her right to abortion despite the fact that the Irish legal system permitted this medical intervention when pregnancy was a threat to the woman's life. ${ }^{17}$ The first applicant's pregnancy was unplanned and it happened when she was facing a series of difficult life situations. She was single and unemployed and had four small children who were, at that time, entrusted to foster care due to her problems with alcohol. ${ }^{118}$ The second applicant stated that she was not capable of taking care of a child at that period of her life. At the beginning of pregnancy, she had some kind of health scare ("a risk of an ectopic pregnancy"), which in the end turned out to be a false alarm. ${ }^{119}$ The third applicant went through chemotherapy due to rare cancer which was in remission at the time when her unplanned pregnancy happened. She was not aware of her pregnancy when she underwent a number of cancer screening tests which are in contradiction with pregnancy. She claimed that "as a result of the chilling effect of the Irish legal framework, she received insufficient information as to the impact of the pregnancy on her health and life". ${ }^{120}$ All three applicants felt stigmatized because they had to go to Great Britain to undergo a medical intervention which was a felony in their country and implied "penal servitude for life". ${ }^{121}$

The Court held that there were substantial differences between the first two applicants who sought an abortion for health and/or well-being reasons and the third one who complained about "the inability to establish her eligibility for a lawful abortion in Ireland", so it made separate decisions on alleged violation of Article 8 of the ECHR. ${ }^{122}$

The ECtHR examined the complaints of the first two applicants in the context of the negative obligations set forth in Article 8 of the ECHR. The reason for such an approach is hidden in the fact that the main argument of the applicants was their assertion that the Irish prohibition of abortion "for health and/or well-being reasons disproportionately restricted their right to respect for their private lives" 123 In compliance with the well-established case-law of the Commission and its earlier case-law, the ECtHR reiterated that every abortion regulation does not interfere

\footnotetext{
117 A., B. and C. v. Ireland, par. 3

118 Ibid., par. 14

119 Ibid., par. 19

120 Ibid., par. 24

121 Ibid., par. 119; See also par. 126

122 Ibid., par. 214

123 Ibid., par. 216
} 
with the right to respect for the private life of pregnant women. ${ }^{124}$ Article 8 of the ECHR can be interpreted neither in a way that termination of pregnancy is deemed exclusively part of a woman's private life ${ }^{125}$ nor as if it provided the right to abortion: ${ }^{126}$

"whenever a woman is pregnant (...) her private life thus becomes closely connected with the developing foetus. A woman's right to respect for her private life must be weighed against other competing rights and freedoms invoked, including those of the unborn child". ${ }^{127}$

It is apprehensible that a decision on abortion performance is not something that is meant under "conventional privacy". ${ }^{28}$ Since that was violation of a negative obligation, the ECtHR carried out its tripartite test and hence established that the legality criterion had been met and that the abortion restrictions were accompanied with legitimate aims since they

"were based on profound moral values concerning the nature of life, which were reflected in the stance of the majority of the Irish people against abortion during the 1983 referendum and which have not been demonstrated to have changed significantly since then. " 129

When deciding on whether the interference with this right was "necessary in a democratic society", the ECtHR believed that there had been a consensus among the contracting states on the grounds for the permissibility of abortion, which were generally broader than those in Ireland. ${ }^{130}$ Yet, in accordance with the Vov. France case, where it was found that the question of when the right to life begins is a matter that falls within the states' margin of appreciation, the Court stated that the Irish State shall generally be allowed a wide margin of appreciation with respect to determining whether a fair balance has been established in relation to the protection of the right to life of the unborn under Irish law and the applicants' right to respect for their private life under Article 8 of the ECtHR.

124 Ibid. The court referred to the cases Bruggemann and Scheuten $v$ Federal Republic of Germany (1981) 3 EHRR 244, par. 59, and Vo v. France, par. 76. For more details, see Scott, op. cit., note 18, p. 4; Fenwick, op. cit., note 116, p. 216

125 Ibid., par. 213; Fabbrini, op. cit., note 1, pp. 51-2

126 Ibid., par. 214; Fabbrini, op. cit., note 1, pp. 51-2

127 Ibid., par. 213

128 Sunstein, C. R., Neutrality in constitutional law (with special reference to pornography, abortion, and surrogacy, Columbia Law Review, vol. 92, 1992, p. 31

129 A., B. and C. v. Ireland, par. 226

130 Ibid., par. 235 
Therefore, in regard to the first two applicants, the ECtHR found that the prohibition of termination of the applicants' pregnancies sought for reasons of health and/or well-being amounted to an interference with their rights under Article 8 of the ECHR, ${ }^{131}$ although this prohibition does not constitute an unjustified interference. The third application was interpreted differently by the ECtHR who found breach of the ECHR in the sense that Ireland had not provided for "an accessible and effective procedural mechanisms" for exercising her right to legal abortion when the expectant's life was in danger. ${ }^{132} \mathrm{The}$ ECtHR added that it came to violation of Article 8 since

"the authorities failed to comply with their positive obligation (emphasis added) to secure to the third applicant effective respect for her private life by reason of the absence of any implementing legislative or regulatory regime providing an accessible and effective procedure by which the third applicant could have established whether she qualified for a lawful abortion in Ireland in accordance with Article 40.3.3 of the Constitution." 133

The applicants also complained about violation of Article 14 of the ECHR in conjunction with Article 8 thereof. ${ }^{134}$ They claimed that the then applicable Irish abortion restrictions were discriminatory and imposed "an excessive burden on them as women and, in particular, on the first applicant as an impoverished woman". ${ }^{135}$ The Court's reply was brief and was not accompanied with a thorough explanation. The ECtHR just asserted that "the Court does not consider it necessary to examine the applicants' complaints separately under Article 14 of the Convention". .136

Beside violation of Article 14 in conjunction with Article 8 of the ECHR, the applicants as well complained about violation of the positive and negative obligations of the state, laid down in Article 3 of the ECHR, which was not taken into consideration by the ECtHR either. ${ }^{137}$

"They maintained that the criminalisation of abortion was discriminatory (crude stereotyping and prejudice against women), caused an

\footnotetext{
$131 \quad$ Ibid., par. 216

132 Fabbrini, op. cit., note 1, pp. 4, 75

133 A., B. and C. v. Ireland, par. 267. Cf. Fabbrini, op. cit., note 1, pp. 4, 75, 58

134 Ibid., par. 269

135 Ibid.

136 Ibid., par. 270. Cf. Fenwick, op. cit., note 116, p. 234

137 Ibid., par. 162
} 
affront to women's dignity and stigmatised women, increasing feelings of anxiety. The applicants argued that the two options open to women - overcoming taboos to seek an abortion abroad and aftercare at home or maintaining the pregnancy in their situations - were degrading and a deliberate affront to their dignity (...) Indeed, the applicants contended that the State was under a positive obligation to protect them from such hardship and degrading treatment." 138

In the case $R$. R. v. Poland (2011), the applicant did not have sufficient information about the condition of her unborn child for six weeks, i.e. from the moment when the first ultrasound scan aroused suspicion of a congenital defect ${ }^{139}$ to the moment when genetic testing (amniocentesis $\left.{ }^{140}\right)^{141}$ confirmed the presence of Turner syndrome. ${ }^{142}$ Unfortunately, at that time, the legally prescribed deadline for making an informed choice of termination of pregnancy had already expired. ${ }^{143}$

However, beside violation of Article 8 (1) of the ECHR, the ECtHR made, according to some authors, "an unprecedented move" 144 and established that Poland breached Article 3 of the ECHR, which bans torture and inhuman or degrading treatment. ${ }^{145}$ Unlike the right to respect for private and family life, laid down in Article 8 of the ECHR, the right not to be subject to inhuman or degrading treatment is regarded as an absolute right. ${ }^{146}$

According to the settled case-law of the ECtHR, ill treatment shall reach "a minimum level of severity" in order to fall within the stipulation in Article 3 of the ECHR. ${ }^{147}$ An assessment if that was the case is relative and should be made taking account of all the referring circumstances, inter alia, "the duration of the treat-

\footnotetext{
$138 \quad$ Ibid., par. 162

139 Judgement R. R. v. Poland (2011) 53 EHRR 31. See Partly Dissenting Opinion of Judge Bratza, par. 2

$140 \quad$ R. R. v. Poland, Partly Dissenting Opinion of Judge Bratza, par. 2

141 Fabbrini, op. cit., note 1, p. 60; R.R. v. Poland, par. 159

${ }_{142}$ R. R. v. Poland, Partly Dissenting Opinion of Judge Bratza, par. 2

143 Fabbrini, op. cit., note 1, p. 60; R.R. v. Poland (2011), App. No. 27617/04, par. 159

144 Fabbrini, op. cit., note 1, p. 60. Fenwick describes this situation as "a very important breakthrough". Fenwick, op. cit., note 116, pp. 233-4

145 Judgement R.R.v. Poland (2011), par. 161

146 It is not explicitly designated as such in the ECHR, this characterization originates from human rights discourse and from the case law of the ECtHR. Addo, M. K.; Grief, N., Does Article 3 of The European Convention on Human Rights enshrine absolute rights? European Journal of International Law, vol. 9 , no. 3, 1998, pp. 512-3

${ }_{147}$ R.R. v. Poland, par. 148. See also Fabbrini, op. cit., note 1, p. 60
} 
ment, its physical and mental effects and, in some cases, the sex, age and state of health of the victim". ${ }^{148}$

The ECtHR held that due to the hesitation of medical workers, the applicant was "in a situation of great vulnerability". ${ }^{149}$ For weeks, she had to live in suspense since "her concerns were not properly acknowledged and addressed by the health professionals dealing with her case". ${ }^{150}$ The ECtHR agreed with the assessment of the Polish Supreme Court, asserting that the applicant was "humiliated", and underlined that her "suffering" was reinforced by the fact that the diagnostic services she needed were available to her and she was entitled thereto pursuant to Polish legislation. ${ }^{151}$

In the case of $P$. and S. $v$. Poland (2012), which concerns an unwanted minor pregnancy resulting from rape, the ECtHR also found violation of Article 8 and Article 3 of the ECHR. ${ }^{152}$

In the context of the positive obligations of the state, the ECtHR observed the right of medical professionals to a conscientious objection. The settled case-law of the ECtHR acknowledged the superiority of individual moral principles over positive law or in this case, the superiority of the right of medical professionals to a conscientious objection. ${ }^{153}$ Yet, after Polish legislation had recognized that right of medical staff, it had a correlative (positive) obligation to ensure a legal framework for arranging that the exercise of that right in practice does not affect access to a lawful abortion, which was the case here. ${ }^{154}$ The ECtHR noted that the right to a conscientious objection shall be adapted to a patient's interests and be accompanied with appropriate procedural guarantees or obligations of conscientious objectors to refer their patients to their colleagues who possess competences to provide a respective medical service.

"However, it has not been shown that these procedural requirements were complied with in the present case or that the applicable laws governing the exercise of medical professions were duly respected." 155

\footnotetext{
148 R.R. v. Poland, par. 148. See also Fabbrini, op. cit., note 1, p. 60

149 R.R. v. Poland (2011), par. 159. Fabbrini, op. cit., note 1, p. 60

150 Judgement R.R. v. Poland, par. 159. Fabbrini, op. cit., note 1, p. 60

151 Ibid., par. 160

152 Fenwick, op. cit., note 116, p. 234; Judgement P. and S. v. Poland (2012), App. No. 57375/08

153 Judgement $P$. and S. v. Poland (2012), App. No. 57375/08, par. 70

154 Ibid., par. 93

155 Ibid., par. 107
} 
The Court reasserted that "the approach of the authorities was marred by procrastination, confusion and a lack of proper and objective counselling and information" ${ }^{156}$ After having been admitted to hospital, the first applicant and the second one, her mother, were exposed to massive stress. Among other things, the chief doctor wanted to impose his viewpoint on the first applicant. ${ }^{157}$ The applicant was forced to talk, regardless of her wishes, with a priest and the case ended up in media based on a hospital's press release. ${ }^{158}$ Due to the conduct of the authorities, the ECtHR also found, beside violation of Article 8, violation of Article 3 of the ECHR. ${ }^{159}$

Finally, although they do not directly concern the foetal right to life, two cases from February 2020 need to be singled out too. The applicants sued Sweden for the inability to work as midwifes in delivery clinics due to their opposition to abortion. In the case of Steen $v$. Sweden, the applicant complained about the prohibition of her employment as a midwife by the Swedish authorities and thus violation of her right guaranteed in Article 9 of the ECHR, which promotes "freedom of thought, conscience and religion". She also complained about violation of Article 10 of the ECHR because her opinion differed from that of the hospital and in the end, of the state. ${ }^{160}$ She added that Article14 of the ECHR was breached as well. ${ }^{161}$ Since the applicant did not lodge a complaint according to Article 14 of the ECHR before national courts, the ECtHR rejected her complaint due to non-exhaustion of domestic remedies (Article $35 \$ \$ 1$ and 4). ${ }^{162}$

In the second case, Grimmark v. Sweden, the applicant also complained, because of her inability to work as a midwife, about violation of Articles 9, ${ }^{163} 10^{164}$ and 14 of the ECHR. ${ }^{165}$ The ECtHR rejected the complaint as "manifestly ill-founded" pursuant to Article $35 \$ \$ 3$ (a) and 4 of the ECHR. ${ }^{166}$ The Court pointed to the positive obligation of the state to arrange its health care system in a way that the exercise of the personal freedom of medical staff to manifest religion or belief does not interfere with their provision of medical services:

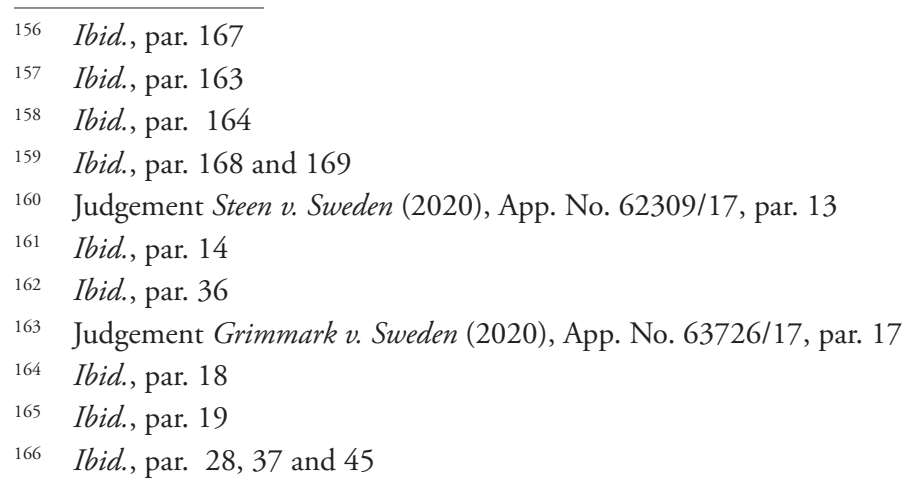


"The Court observes that Sweden provides nationwide abortion services and therefore has a positive obligation to organise its health system in a way as to ensure that the effective exercise of freedom of conscience of health professionals in the professional context does not prevent the provision of such services. The requirement that all midwives should be able to perform all duties inherent to the vacant posts was not disproportionate or unjustified."167

\subsection{Case law of the Court of Justice of the European Union}

The CJ played an important role in the transition of the European Union from an international institution into a supranational constitutional structure guaranteeing individual rights. ${ }^{168}$ With respect to abortion and the case-law of this Court, it is important to mention the case of the Society for the Protection of Unborn Children Ireland Ltd $v$ Stephen Grogan and others (1991). ${ }^{169}$ In that case, the CJ was invited to deliver a ruling considering "the preliminary reference procedure from the Irish High Court". The Society for the Protection of the Unborn Child Ltd (hereinafter SPUC), the plaintiff in the main proceedings, was a company engaged in the prevention of decriminalization of abortion in Ireland. ${ }^{170}$ It required injunction aimed at prohibition of dissemination of information on foreign abortion providers ${ }^{171}$ by the defendants in the main proceedings, Stephan Grogan and representatives of several student organizations. ${ }^{172}$ The application for the prohibition resulted from violation of the Eight Amendment of the Constitution of Ireland. In its answer to the question of the national court, the CJ stated that the medical termination of pregnancy, performed in compliance with the legal rules of the respective country, represents a service depicted in Article 60 of the EEC Treaty. ${ }^{173}$ It is not contrary to community law, emphasized the CJ, for a contracting state to ban student associations to disseminate information on foreign clinics providing abortion if those clinics are not involved in the distribution of controversial information. ${ }^{174}$

\footnotetext{
167 Ibid., par. 26

168 Cichowski, R. A., Women's rights, the European Court, and supranational constitutionalism, Law \& Society Review, vol. 38, no. 3, 2004, p. 489

169 Case C-159/90 The Society for The Protection of Unborn Children Ireland Ltd V Stephen Grogan and Others [1991]. See Fabbrini, op. cit., note 1, pp. 23-4

170 Grogan, par. 6

171 Ibid., par. 6

172 Fabbrini, op. cit., note 1, pp. 23-4

173 Grogan, par. 21. Fabbrini, op. cit., note 1, p. 25

174 Ibid., par. 32
} 
The CJ especially concentrated on the question when life begins in the case of Oliver Brüstle v. Greenpeace e.V. (2011), in which it determined "that any human ovum must, as soon as fertilised, be regarded as a 'human embryo' within the meaning and for the purposes of application of Article 6(2)(c) of Directive" 98/44/EC of the European Parliament and of the Council of 6 July 1998 on the legal protection of biotechnological inventions. ${ }^{175}$ Although this interpretation has led some authors to conclude that, by this decision, the CJ defined the beginning of human life (e.g. Hrabar states that in this decision "for the first time in the current legal science and judicature, an explicit view is expressed that human life begins at the moment of fertilisation when a sperm fertilises an egg or ovum, i.e. at the moment of conception. So, undoubtedly, human life (...) begins with conception."), ${ }^{176}$ we do not agree with that conclusion. In this decision, the CJ was very cautious and distanced itself in such a way as to limit the definition of a human embryo to the scope of application of the said Directive. This view can also be seen in the Ruling of the Constitutional Court of the Republic of Croatia of 21 February 2017, stating that even without taking into account the limited scope of application of the definition of a human embryo, it seems that the definition of a human embryo

"cannot be interpreted in this decision as if the term 'human being' were either explicitly or implicitly defined, especially not within the meaning of equal protection extended to live-borns and unborn beings from the moment of conception". ${ }^{177}$

With respect to the issue of abortion at EU level, another case deserves particular attention. On 23 April 2018, the General Court of the European Union dismissed the action submitted by the European Citizens' Initiative with the title "Uno di noi" (One of Us) and seven natural persons who launched this initiative. ${ }^{178}$ The action was aimed at annulment of Communication COM (2014) 355 final on that controversial initiative and, in the alternative, at annulment of Article 10 paragraph 1 item (c) of Regulation (EU) No 211/2011 of the European Parliament and of the Council of 16 February 2011 on the citizens' initiative. ${ }^{179}$ The applicants were supported by the Republic of Poland. On 28 May 2014, the Commission adopted the contested Communication and decided not to take any

\footnotetext{
175 Oliver Brüstle v. Greenpeace e.V., C-34/10, EU:C:2011:669, par. 35

176 Hrabar, D., Pravo na pobačaj-pravne i nepravne dvojbe, Zbornik PFZ, vol.65, no. 6, 2015, p. 816

177 Ruling of the Constitutional Court of the Republic of Croatia, op. cit., note 103, Title VIII, p. 70

178 It must be emphasized that the Court found that the "European Citizens' Initiative One of Us", unlike the seven natural persons who organized it, did not have party capacity, Case T-561/14, European Citizens' Initiative One of $U_{s}$ and Others $v$ European Commission (2018), par. 63

179 Ibid., par. 32
} 
action in regard to the One of US initiative. ${ }^{180}$ The initiative revolved around the protection of the dignity and right to life of every human being from the moment of their conception. In doing so, the initiative touched upon areas regulated by the European Union. ${ }^{181}$ Its goals can be clearly deducted from the internet register:

"The human embryo deserves respect to its dignity and integrity. This is enounced by the [Court of Justice of the European Union] in the Brüstle case, which defines the human embryo as the beginning of the development of the human being. To ensure consistency in areas of its competence where the life of the human embryo is at stake, the [European Union] should establish a ban and end the financing of activities which presuppose the destruction of human embryos, in particular in the areas of research, development aid and public health." 182

Among other things, the applicants complained about violation of Article 10 paragraph 1 item (c) of Regulation (EU) No 211/2011 of the European Parliament and of the Council of 16 February 2011 on the citizens' initiative since the Commission failed to propose a legal document as a response to the controversial initiative. ${ }^{183}$ They claimed that the Commission's right to stay passive should be narrowly interpreted. ${ }^{184}$ Yet, the Commission power of legislative initiative (Article 17 paragraph 2 of the UEU and Article 289 of the UFEU) implies autonomy in making decisions on proposing an act as well as in defining its scope, aim and content. ${ }^{185}$

The Court established that the interpretation of Article 10 paragraph 1 item (c) of Regulation (EU) No 211/2011 by the applicants challenges the discretionary power of the Commission, which is exercised in the form of a legislative initiative with respect to particular European citizens' initiatives. If the Court had accepted the applicants' interpretation, it would have implied that the Commission "shall undertake 'concrete' action" proposed in the respective European citizens' initiative. ${ }^{186}$ The applicants' interpretation is, held the Court, contrary to the Commission's "legislative initiative quasimonopoly" granted in the Treaties and its comprehensive discretionary power exercised while performing its function as a legislative

\footnotetext{
$180 \quad$ Ibid., par. 12

181 Ibid., par. 2

182 Ibid., par. 3

183 Ibid., par. 102

184 Ibid., par. 103

185 Ibid., par. 109

186 Ibid., par. 115
} 
initiative. ${ }^{187}$ When playing its legislative initiative role, the Commission should have broad discretionary powers since it, based thereon (Article 17 paragraph 1 of the UEU- a) should promote the general interest of the Union. ${ }^{188}$

\section{A CRITICAL OVERVIEW}

The European multilevel regulation of human rights protection is characterized by "complex dynamics" ${ }^{189}$ Despite the prevailing viewpoint that there is no lack of legal harmonization between national legal systems that restrictively govern the issue of abortion and the normative order based on the ECHR and EU treaties, ${ }^{190}$ numerous theoretical and practical aspects of the issue of abortion remain unresolved.

The previous case-law of the ECtHR can be denoted as "value free". ${ }^{191}$ Unlike some national constitutional or supreme courts, out of which the American Supreme Court and its management of the case of Roe v. Wade 410 U.S. 113 (1973) need to be singled out, the ECtHR has so far managed to escape establishing both the foetal right to life pursuant to Article 2 of the ECHR ${ }^{192}$ and the woman's fundamental right to abortion in accordance with Article 8 of the same document. ${ }^{193}$ More, it has failed to conduct substantive review of national legislations by establishing a balance between the interest of pregnant women and their foetuses, i.e. the interests of the state in preserving the life of the foetus. ${ }^{194}$

Some eminent critics find such an attitude untenable. Thus, writing in 1994, Williams emphasized that the ECHR is not only a legal but also a moral document. The ECtHR must enforce it in all contracting states. If a foetus is considered a person according to the ECHR in one country, it must logically be considered a person in all the other countries as well. ${ }^{195}$

The scope of deference afforded to states when regulating abortion is still wide. ${ }^{196}$ Violation of the ECHR has been found by the ECtHR in several cases involving

\footnotetext{
$187 \quad$ Ibid., par. 115

188 Ibid., par. 169

189 Fabbrini, op. cit., note 1, p. 34

190 Ibid.

191 Fenwick, op. cit., note 116, p. 229

192 Ibid., p. 214

193 Ibid., p. 229

194 Ibid., p. 239

195 Williams, op. cit., note 25, p. 79

196 Weinstein, op. cit., note 82, p. 402-3
} 
omission of states with restrictive abortion regimes to ensure performance of a legally permitted abortion through "effective" legal procedures. ${ }^{197}$ In regard to the previous case-law of the ECtHR, states have legitimacy or broad discretion to regulate the issue of abortion. However, if they regulate the issue of abortion in a way that they permit performance of abortion on demand in exceptional situations, like Poland or Ireland had prior to 2018, they will have "a positive obligation to create a procedural framework enabling a pregnant woman to effectively exercise her right to access to a lawful abortion". ${ }^{198}$ The adopted legal framework shall not restrain "the real possibilities" of pregnant women to undergo an abortion. Such a framework shall be coherent and enable taking different legitimate interests into account in line with the treaty obligations of a contracting state. ${ }^{199}$ As highlighted by the ECtHR in the case of $P$ and $S v$. Poland, "effective enjoyment of the rights guaranteed" under Article 8 of the ECHR can be achieved if "the relevant decision-making process is fair and such as to afford due respect for the interests safeguarded" thereby. ${ }^{200}$

When a contracting state legally regulates access to abortion, its margin of appreciation gets narrower ${ }^{201}$ and thus the state ceases to enjoy discretion regarding the "manner" in which it intends to make abortion accessible. ${ }^{202}$ The fact that the ECtHR is entitled to monitor the way a contracting state meets its positive obligations set out in Article 8 of the ECHR accounts for the above assertion. ${ }^{203}$ In cases against Poland and Ireland, the ECtHR embraced the argument provided by the states themselves, revealing that they have "effective procedures" for permitting access to an abortion, so in its rulings, it imposed on them respect for their own procedural standards. ${ }^{204}$ In this context, it should be underlined that when medical staff exercise their right to a conscientious objection, an instrument recognized in the case-law of the ECtHR, the contracting states shall still have, according to Article 8 of the ECHR, a positive obligation to provide pregnant women with access to an abortion since that is what their legislation has foreseen anyway.

\footnotetext{
197 Fenwick, op. cit., note 78, p. 249

198 P. and S. v. Poland, par. 99. See also Fenwick, op. cit., note 116, p. 229; Fabbrini, op. cit., note 1, pp. 34-5

199 Ibid., par. 99

200 Ibid., par. 99. See also Feinwick, 2014, 227

201 Scott, op. cit., note 18, p. 8; Black, I., Refusing Life prolonging medical treatment and the ECHR, Oxford Journal of Legal Studies, 2018, p. 27

202 Fenwick, op. cit., note 78, p. 261; Black, op. cit., note 201, p. 27

203 Fenwick, op. cit., note 116, p. 227; Scott, op. cit., note 18, p. 8; Black, op. cit., note 201, p. 27

204 Fenwick, op. cit., note 78, p. 274
} 
Some authors think that the role of the ECtHR is mostly reduced to shaping a framework for "policing the implementation of national abortion infrastructure". ${ }^{205}$ Such a conferred approach has nevertheless allowed the court to create pragmatic protection of pregnant women. ${ }^{206}$ Fenwick might be right when he claims that the ECtHR focuses on and uses "procedural values" as replacement for the protection of substantive values. ${ }^{207}$ The grounds for his claim that the ECtHR does not have only procedural standpoints are set by the fact that the balance between two normative values, ${ }^{208} \mathrm{a}$ woman's right to abortion and the foetal right to life, has "a sensitive nature" and for that reason, it is comprised by the margin of appreciation of the contracting states. ${ }^{209}$ Nonetheless, in its ruling in cases against Ireland and Poland, the ECtHR implicitly recognised the existence of the request towards the contracting states to provide pregnant women with access to an abortion in early stages of their pregnancies if the pregnancies are harmful to their physical integrity. ${ }^{210}$

Furthermore, concerning the status of foetus, the use of language of rights following the principle "all or nothing" is not satisfactory. ${ }^{211}$ The ECtHR still hesitates to tackle the moment when life begins. This issue is not a challenge only to jurists or philosophers but also to biomedical scientists. The idea of "a moment of conception when a new human being is miraculously created" is not compliant with scientific postulates. One cannot speak about, thinks Williams, a "moment" but about a process: "The 'moment' when the two gametes (the sperm and the ovum) fuse resolves itself under the microscope into a succession of clearly discernible stages, which may take 24 hours or more to complete". ${ }^{212}$

In the case of Vo v. France, the ECtHR recognized that foetus belongs to humankind and acknowledged its value related thereto, but it did not provide it with legal rights. ${ }^{213}$ It did also recognize "the potentiality of that being and its capacity to become a person - enjoying protection under the civil law, moreover, in many States, such as France, in the context of inheritance and gifts". ${ }^{214}$ However, Scott

\footnotetext{
205 Fenwick, op. cit., note 116, p. 239

206 Ibid, pp. 228, 239

207 Fenwick, op. cit., note 116, p. 229

208 Fenwick, op. cit., note 78, p. 273

209 Ibid, p. 275

210 Ibid.

211 Scott, R., The English fetus and the right to life, European Journal of Health Law, vol. 11, no. 4, 2004, p. 348

212 Williams, op. cit., note 25, p. 76

213 Scott, op. cit., note 211 , p. 348

214 Vov. France, par. 84
} 
rightly observes that the protection of foetus regarding inheritance refers, from a legal point of view, to the protection of a delivered child since inheritance is related to childbirth. ${ }^{215}$ Similarly, the Croatian legal system does not provide a explicit answer to the question when life begins, but it can be derived therefrom that a human being as a holder of rights and duties comes into existence with his/her birth. ${ }^{216}$ "Potential persons" who may but does not have to "come into existence" are persons neither in the legal nor in the philosophical sense. ${ }^{217}$

Foetuses and embryos have been believed to belong to human race since the very beginning. This is not challenged. What is in dispute is should they be granted the same protection as those who have already been born. ${ }^{218}$ There is a difference between the recognition of foetal rights and the protection of its interests in a way that is not based on rights. ${ }^{219}$ Scott should be supported when she promotes further development of the protection of foetus from circumstances pertaining to scientific and technological advancement (genetic engineering or embryo experimentation), though without changing the current legal balance between the interests of the foetus and the mother. ${ }^{220}$

What some authors, like Fabbrini and Fenwick, believe is that ECtHR lacks, due to its focus on procedural issues, substantive protection of women from ill treatment on the grounds of the bare fact that they are women. ${ }^{221}$ Both authors tackle the standpoint of the ECtHR not to accept complaints about discrimination when assessing the abortion legislation of some contracting states. Moreover, the ECtHR did not seriously consider the applicants' allegations that strict limitation of access to a lawful abortion may be deemed as gender discrimination. ${ }^{222}$ For instance, the claim of the applicants in the case $A ., B$. and C. v. Ireland. ${ }^{223}$

Although Article 14 of the ECHR cannot exist autonomously, its effect is evident with respect to the exercise of the rights and freedoms laid down in other substantive provisions of the ECHR. ${ }^{224}$ Here is relevant reasoning from the case Grimmark v. Sweden:

\footnotetext{
215 Scott, op. cit., note 211 , p. 352

216 Williams states that this is also the case under English law. The child must be outside the mother's womb and be able to breathe. Williams, op. cit., note 25, p. 71

217 Andorno, op. cit., note 114, p. 228

218 Williams, op. cit., note 25, p.78

219 Scott, op. cit., note 211, pp. 351-2

220 Ibid., p. 348

221 Fenwick, op. cit., note 116, p. 215

222 Fenwick, op. cit., note 116, p. 229

223 A., B. and C. v. Ireland, par. 162

224 Grimmark v. Sweden, par. 40
} 
"in order for an issue to arise under Article 14, there must be a difference in treatment of persons in relevantly similar situations. Such a difference of treatment is discriminatory if it has no objective and reasonable justification; in other words, if it does not pursue a legitimate aim or if there is not a reasonable relationship of proportionality between the means employed and the aim sought to be realised." 225

When assessing whether it came to a different treatment of persons who were affected by the same problems in different contracting states, the ECtHR again did not want to interfere with their margin of appreciation. ${ }^{226}$ In Fenwick's opinion, ECtHR judgements lack"gender-based elements" 227.

"Stigmatisation of women, stress and medical risks linked to restrictive regimes under Article 8. Recognition of the adverse effects on a woman's dignity and mental integrity of stigmatisation of abortion-seekers was largely absent from the jurisprudence." 228

The ECtHR took a significant step forward when it established that it came to violation of Article 3 of the ECHR in the case of $R . R . v$. Poland and in the case of $P$. and S. v. Poland. However, it should have done more, holds Fenwick, and confirmed that the applicants were exposed to discrimination according to Article 14 of the ECHR in a situation which is unique for women. ${ }^{229}$ Interestingly, this important moment in the case-law of the ECtHR, i.e. sanctioning the contracting states for inhuman and degrading treatment of the applicants, has not been incorporated into the Ruling of the Croatian Constitutional Court on rejecting the proposal for assessment of the constitutionality of the applicable Croatian act regulating the issue of abortion. ${ }^{230}$

States with restrictive abortion regimes directly discriminate against women, claims Fenwick, because they treat women differently for the bare fact that only women can get pregnant. ${ }^{231}$

The ECtHR did acknowledge that the "suffering" which the Polish applicants had gone through could be regarded as violation of their rights, but it did not ascer-

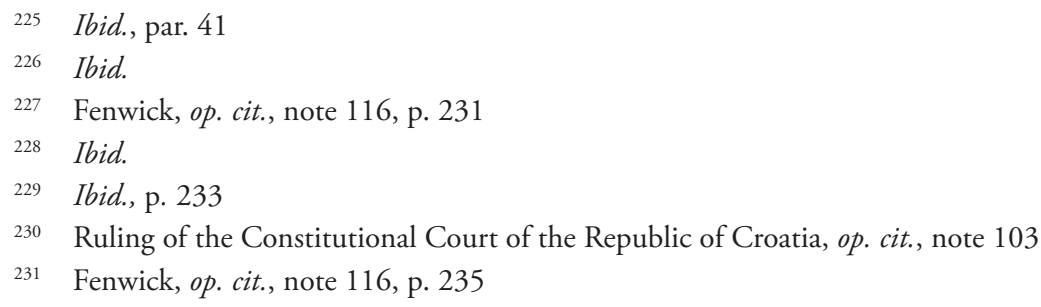


tain "that highly restrictive abortion regimes systematically and persistently create especially invidious discrimination based on gender." ${ }^{232}$

Unlike Fenwick, Fabbrini explores both the case-law of the ECtHR and the caselaw of the CJ in regard to the permissibility of abortion. He indicates that here one can also talk about discrimination based on the financial status of pregnant women. Even though there are no common directives referring to abortion at EU level, ${ }^{233}$ gender equality represents one of the foundational norms of the European Union which has played a prominent role in the promotion of "gender equality laws and policies". ${ }^{234}$

The EU Member States that do not permit abortion on demand at all or have rather restrictive abortion legislation permitting only few exceptions shall, in accordance with European law and relevant case-law, allow pregnant women to obtain information on undergoing abortion in countries with a more liberal abortion regime and grant them immunity from any sanctions when they return to their homeland. ${ }^{235}$ Such abortion regulation results in discrimination against women with low income, who cannot afford to travel abroad to have an abortion. ${ }^{236}$

Due to such abortion regulation in the complex European constitutional structure, abortion has become part of cross-border reproductive care. ${ }^{237}$ Expectants choose to travel from countries with a rigorous approach to abortion to countries with a more liberal approach thereto. In line with UK Government's abortion statistics for the year 2013, 3,679 Irish citizens underwent abortion in England and Wales. Moreover, the real number is even bigger since the statistics encompass only women who disclosed their Irish residence when having been admitted to hospital. ${ }^{238}$ In Mulingan's opinion, if the majority of Irish women had not had access to foreign abortion providers, the strict Irish abortion legislation would have been put under massive pressure and probably, have liberalized sooner. ${ }^{239}$ As far as Poland is concerned, the official statistics reveal that only 1,000 induced abortions are performed in Poland on an annual basis while the real figures are much bigger,

\footnotetext{
232 Ibid., p. 214

233 Guillaume, A.; Rossier, C., Abortion around the world. An overview of legislation, measures, trends, and consequences, "Population” (English edition) Institut National d'Études Démographiques (INED), No. 2,2018 , p. 235

234 Vida, op. cit., note 58, p. 13

235 Fabbrini, op. cit., note 1, p. 68

236 Ibid., p. 70

237 Mulligan, op. cit., note 41, p. 266

238 Ibid., p. 260

239 Ibid., p. 266
} 
the estimates mention 150,000 abortions per year. Most of them are performed in foreign clinics and lots of women take the so-called abortion pills. ${ }^{240}$

When criticizing the case-law of European courts, Fabbrini obviously relies on the criticism of the establishment of the right to abortion in the United States. Decades after the case of Roe v. Wade, prominent American jurists stressed that the right to abortion should have been based on the equal protection clause of the Fourteenth Amendment to the United States Constitution instead on the right to privacy. ${ }^{241}$ Per Ruth Bader Ginsburg and her opinion on the issue of abortion, the real conflict does not reflect in the opposing interests of the foetus and state on one side and those of the pregnant woman on the other side but it relates to the independence and equality of the woman. ${ }^{242}$ In his well-known article Neutrality in constitutional law (with special reference to pornography, abortion, and surrogacy, Cass Sustein indicates that pregnancy as a woman's biological ability entails "social consequences" in the form of involuntary pregnancy only due to the State's decision on the prohibition or restriction of abortion. ${ }^{243}$ Such restrictions are not controversial because of the violation of a woman's bodily integrity but because of the way the state imposes them on women, i.e. it foresees different roles for persons considering their affiliation to a certain gender and hence, women are treated as second-class citizens. ${ }^{244}$

"A law that explicitly and exclusively relates to women, i.e. that contains a gender-based legal distinction is unquestionably a form of gender discrimination". 245

According to Fabbrini, it is up to the CJ to undertake appropriate steps for the purpose of combatting discrimination against women in the context of abortion. ${ }^{246}$ Fabbrini adds that if based on the CFR, the CJ opted, together with national courts, for review of the restrictive abortion legislation of some Member States, it could contribute to establishment of a new regime which would not jeopardize the

240 Shaun Walker, Pro-choice activists launch abortion initiative in Poland, 10 December 2019, [https:// www.theguardian.com/world/2019/dec/10/pro-choice-activists-launch-abortion-initiative-in-poland], accessed 10. January 2020

241 Fabbrini, $o p$. cit., note 1, p. 68. For more discussion of this topic, see Blagojević, A.; Tucak, I., Rethinking the Right to Abortion, Balkan Social Science Review, vol. 15, no. 15, 2020, pp. 135-157

242 Ginsburg, R. B., Some thoughts on autonomy and equality in relation to Roe v. Wade, N.C. L. Rev., vol. 63, 1985, p. 383

243 Sunstein, op. cit., note 128, p. 33

244 Ibid., p. 39

245 Ibid., p., 32

246 Fabbrini, op. cit., note 1, p. 71 
equality principle. ${ }^{247}$ Indeed, the hard pluralism affecting Europe in this light today, which can be derived from the fact that regardless of rising consensus among the Member States on abortion liberalization, legal difference between them still persist, ${ }^{248}$ might soften considerably if the above steps are undertaken. ${ }^{249}$ Pursuant to the aforementioned, a woman's right to abortion in early stages of pregnancy would be thus recognized at supranational level while the Member States could retain their possibility to regulate it at national level in accordance with their internal circumstances. ${ }^{250}$

Although a woman's right to abortion is protected in Europe in a way and women in countries with restrictive abortion regimes have the right to information on foreign abortion providers, it would be good if the right to abortion as an autonomous fundamental right was recognized at European level. As communicated by legal theoretician Richard Flatham, by granting the right to abortion, societies would demonstrate the highest level of respect for the autonomy of every agent. ${ }^{251}$ Providing a right to do $\mathrm{X}$ in particular jurisdiction means that doing $\mathrm{X}$ should be deemed "correct" or "blameless" irrespective of the existence of society members who oppose such qualification. ${ }^{252}$

Fenwick emphasizes that the case-law of the ECtHR can be criticized on account of its implicit permission provided to "the European consensus doctrine" to govern the scope of an accepted margin of appreciation. ${ }^{253}$ In doing so, Feinwick paraphrases George Letsas who, when discussing the relation between consensus and public moral, accentuates that the ECtHR allows, contrary to liberal views, communal morality to supersede individual rights. ${ }^{254}$

Ivana Radačić also criticizes the interpretation of morals and consensus by the ECtHR. The author points out that giving priority to the decision of a particular country when there is no consensus between the Member States on the issue of sexual morality prevents "effective protection" of the rights provided for in the ECHR, especially in case of vulnerable groups. Their rights can be equally jeopardized by the demand to be accepted "by the majority of states" as by "the majority within a state". The ECtHR, Radačić argues, must not provide states with

\footnotetext{
$247 \quad$ Ibid., p. 73

248 Ibid., p.72

249 Ibid., p. 73

250 Ibid.

251 Flatham, op. cit., note 20, p. 170

252 Ibid., p. 169. For more discussion of this topic, see Blagojević; Tucak, op. cit., note 241, pp. 135-157

253 Fenwick, op. cit., note 116, p. 222

254 Letsas, op. cit., note 82, pp 92-98
} 
a margin of appreciation in deciding on the standards imposed by the ECHR. In determining a standard, the ECtHR should not be guided by a consensus but by the values of individual autonomy, dignity and equality. ${ }^{255}$

\section{CONCLUDING THOUGHTS}

A woman's access to a safe and legal abortion in Europe remains a pending issue in the $21^{\text {st }}$ century. The abortion legislation in the Republic of Ireland has changed in 2018 for the sake of its harmonization with international standards of human rights protection and that change partially results from the action of European courts. ${ }^{256}$ Something similar happened in Northern Ireland where on 31 March 2020, the Abortion (Northern Ireland) Regulations 2020 came into force. ${ }^{257}$

On the other hand, such a trend is not universally applicable. In some Central and Eastern European countries, the issue of abortion is related to negative demographic trends and performance of abortion is considered unpatriotic. ${ }^{258}$ In April 2020, the Polish Parliament postponed making a final decision on the bill aimed at tightening its abortion regime in the sense of banning one of the three exceptions to abortion prohibition - serious foetal abnormality. The bill was returned to the parliamentary committee for additional elaboration. The proposal for this restriction originates from a citizens' initiative launched by a Catholic group who succeeded in gathering more than 100,000 signatures, which makes this topic eligible for being discussed in the Parliament (Sejm). The majority in the Sejm is, by the way, constituted by the right-wing Law and Justice (PiS) party. ${ }^{259}$

Strict abortion legislation remains a terrible example of turning "a priori morality into law". ${ }^{260}$ The ECtHR recently did recognize the suffering of the Polish applicants as violation of their rights to private and family life (Article 8) and to be free from inhuman or degrading treatment (Article 3). However, we agree with authors, like Fenwick and Fabbrini, who believe that it is vital to take one step

\footnotetext{
255 Radačić, I., The margin of appreciation, consensus, morality and the rights of the vulnerable groups, Zbornik Pravnog Fakulteta Sveučilišta u Rijeci, vol. 31, no. 1, 2010, p. 600

256 Mulligan, op. cit., note 41, p. 266

257 McGuinness, S.; Rooney, J., A legal landmark in reproductive rights: The Abortion (Northern Ireland) Regulations 2020. [Web log post], 1 April 2020, [https://legalresearch.blogs.bris.ac.uk/2020/04/a-legal-landmark-in-reproductive-rights-the-abortion-northern-ireland-regulations-2020/], accessed 20 . April 2020

258 Fenwick, op. cit., note 116, p. 217

259 Shaun Walker, Polish parliament delays decision on new abortion restrictions, 19 April 2020, [https:// www.theguardian.com/world/2020/apr/16/polish-parliament-delays-decision-on-new-abortion-restrictions], accessed 20. April 2020

260 Williams, op. cit., note 25 , p. 76
} 
further. It is vital to establish that states with restrictive abortion regimes directly discriminate against women, because they treat women differently for the bare fact that only women can get pregnant. ${ }^{261}$ The right to abortion differs from other reproductive rights, such as the right to contraception, in that, unlike contraception, which is important for members of both sexes, the right to abortion directly affects only women. ${ }^{262}$ Such abortion regulation results in discrimination against women with low income, who cannot afford to travel abroad to have an abortion, ${ }^{263}$ which generally undermines the equality principle. ${ }^{264}$

Although a woman's right to abortion is protected in Europe in a way and women in countries with restrictive abortion regimes have the right to information on foreign abortion providers, it would be good if the right to abortion as an autonomous fundamental right was recognized at European level. ${ }^{265}$ Such recognition is required to, as mentioned by the applicants in the case of $A, B$ and $C v$. Ireland, eliminate stigmas, anxieties and insults to a woman's dignity. ${ }^{266}$ The dangers to a woman's life and health, which strict abortion legislation accounts for, came to the fore earlier this year when the COVID-19 pandemic closed state borders and made it impossible for women to travel to undergo an abortion in countries with more liberal abortion regimes. ${ }^{267}$

\section{REFERENCES}

\section{BOOKS AND ARTICLES}

1. Addo, M. K.; Grief, N., Does Article 3 of The European Convention on Human Rights Enshrine Absolute Rights? European Journal of International Law, vol. 9, no. 3, 1998, pp. 510-524

2. Andorno, R., Human Dignity and Human Rights as a Common Ground for a Global Bioethics, The Journal of Medicine and Philosophy: A Forum for Bioethics and Philosophy of Medicine, vol. 34, no. 3, 2009, pp. 223-240

3. Baldissone, R., Human rights: a lingua franca for the multiverse, The International Journal of Human Rights, vol. 14, No. 7, 2010, pp. $1117-1137$

261 Fenwick, op. cit., note 116, p. 235

262 Hunt; Gruszczynski, op. cit., note 12, pp. 730-1

263 Fabbrini, op. cit., note 1, p. 70

264 Ibid., p. 73. Article 21 The Charter of the European Union prohibits discrimination on the grounds of gender, but also on the basis of property. Fabbrini, op. cit., note 1, p. 71

265 Flathman, op. cit. note 20, pp. 169-170

$266 A, B$ and $C$ v. Ireland, par. 162

267 Megan Clement; Bertrand Borg, How Malta's abortion taboo leaves women in despair, 11 June 2020, [https://www.theguardian.com/world/2020/jun/11/like-ireland-on-steroids-maltas-abortion-tabooleaves-women-in-despair], accessed 11. June 2020 
4. Black, I., Refusing Life prolonging medical treatment and the ECHR, Oxford Journal of Legal Studies, 2018, pp. 1-29, doi:10.1093/ojls/gqy009

5. Blagojević, A.; Tucak, I., Rethinking the Right to Abortion, Balkan Social Science Review, vol. 15 , no. 15,2020 , pp. $135-157$

6. Cichowski, R. A., Women's Rights, the European Court, and Supranational Constitutionalism, Law \& Society Review, vol. 38, no. 3, 2004, pp. 489-512

7. Copelon, R.; Zampas, C.; Brusie, E.; de Vore, J., Human Rights Begin at Birth: International Law and the Claim of Fetal Rights, Reproductive Health Matters, vol. 13, no. 26, 2005, pp. 120-129

8. Dixon, R.; Nussbaum, M. C., Abortion, dignity, and a capabilities approach, in: Baines, B.; D. Barak-Erez, D.; Kahana, T. (eds.), Feminist constitutionalism: Global perspectives, Cambridge University Press, 2012, pp. 64-82

9. Fabbrini, F., The European Court of Human Rights, the EU Charter of Fundamental Rights and the right to abortion: Roe v. Wade on the other side of the Atlantic? Columbia Journal of European Law, vol. 18, no. 1, 2011, pp. 1-72

10. Fenwick, D., The Modern Abortion Jurisprudence under Article 8 of the European Convention on Human Rights, Medical Law International, vol. 12, no. 3-4, 2013, pp. 249-276

11. Fenwick, D., "Abortion Jurisprudence" at Strasbourg: Deferential, Avoidant and Normatively Neutral? Legal Studies, vol. 34, no. 2, 2014, pp. 214-241

12. Fine, J. B.; Mayall, K.; Sepúlveda, L., The role of international human rights norms in the liberalization of abortion laws globally, Health and Human Rights, vol. 19, no. 1, 2017, pp. 69-80

13. Flathman, R., Toward a liberalism, Cornell University Press, Ithaca, London, 1989

14. Ginsburg, R. B., Some thoughts on autonomy and equality in relation to Roe v. Wade, N.C. L. Rev., vol. 63, 1985, pp. 375-386

15. Gravino, G.; Caruana-Finkel, L., Abortion and methods of reproductive planning: the views of Malta's medical doctor cohort, Sexual and Reproductive Health Matters, vol. 27, no. 1, 2019, pp. 287-303

16. Guillaume, A.; Rossier, C., Abortion around the world. An overview of legislation, measures, trends, and consequences, "Population" (English edition) Institut National d'Études Démographiques (INED), No. 2, 2018, pp. 217-306

17. Hrabar, D., Pravo na pobačaj-pravne i nepravne dvojbe, Zbornik PFZ, vol. 65, no. 6, 2015, pp. 791-831

18. Hunt, K.; Gruszczynski, M., The Ratification of $C E D A W$ and the Liberalization of Abortion Laws, Politics \& Gender, vol. 15, no. 4, 2019, pp. 722-745

19. Letsas, G., A Theory of Interpretation of the European Convention on Human Rights, Oxford University Press, 2009

20. Mulligan, A., The Right to Travel for Abortion Services: A Case Study in Irish Cross-Border Reproductive Care, European Journal of Health Law, vol. 22, no. 3, 2015, pp. 239-266

21. Nys, H., Towards an International Treaty on Human Rights and Biomedicine? Some Reflections Inspired by UNESCO's Universal Declaration on Bioethics and Human Rights, European Journal of Health Law, vol. 13, no. 1, pp. 5-8. 
22. Radačić, I., The margin of appreciation, consensus, morality and the rights of the vulnerable groups, Zbornik Pravnog Fakulteta Sveučilišta u Rijeci, vol. 31, no. 1, 2010, pp. 599-616

23. Senden, H., Interpretation of the Fundamental Rights in a Multilevel Legal System, Intersentia, 2011

24. Scott, R., The English Fetus and the Right to Life, European Journal of Health Law, vol. 11, no. 4, 2004, pp. $347-364$

25. Scott, R., Risks, Reasons and Rights: The European Convention on Human Rights and English Abortion Law, Medical Law Review, vol. 24, no. 1, pp. 1-33, doi: 10.1093/medlaw/fwv020 Advance Access Publication: November 6, 2015

26. Stašević, I.; Ropac, D., Statistički podaci o pobačajima u Hrvatskoj-neke osobitosti i usporedbe, Društvena istraživanja, vol. 27, no. 2, 2018, pp. 345-362

27. Sunstein, C. R., Neutrality in constitutional law (with special reference to pornography, abortion, and surrogacy, Columbia Law Review, vol. 92, 1992, pp. 1-52

28. Vida, B., New waves of anti-sexual and reproductive health and rights strategies in the European Union: the anti-gender discourse in Hungary, Sexual and Reproductive Health Matters, vol. 27, no. 2, 2019, pp. 13-16

29. Weinstein, B., Reproductive Choice in the Hands of the State: The Right to Abortion under the European Convention on Human Rights in Light of $A, B \& C v$. Ireland, American University International Law Review, vol. 27, no. 2, 2012, pp. 391-438

30. Williams, G., The Fetus and the "Right to Life" The Cambridge Law Journal, vol. 53, no, 1, 1994, pp. 71-80

31. Zorzi, K., The impact of the United Nations on National Abortion Laws, Catholic University Law Review, vol. 65, no. 2, 2015, pp. 409-428

\section{COURT OF JUSTICE OF THE EUROPEAN UNION}

1. Case C-159/90 The Society for The Protection of Unborn Children Ireland Ltd v. Stephen Grogan and Others [1991] E.C.R. I-4685

2. Case C-34/10 Oliver Brüstle v. Greenpeace e.V. [2011], 18 October 2011

3. Case T-561/14 One of Us v. Commission, EU:T:2018:210

\section{ECHR}

1. European Convention for the Protection of Human Rights and Fundamental Freedoms, as amended by Protocols Nos. 11 and 14, 4 November 1950, ETS 5

2. A., B. and C v. Ireland (2011) 53 E.H.R.R 13

3. Boso v. Italy (2002), App. No. 50490/99, Eur. Ct. H.R. 846

4. Grimmark v. Sweden (2020), No. 63726/17

5. H. v. Norway (1992) 73 DR 155

6. Paton v. United Kingdom (1981) 3 EHRR 408

7. P. and S. v. Poland (2012), No. 57375/08

8. R. R. v. Poland (2011) 53 EHRR 31 
9. Steen v. Sweden (2020), No. 62309/17

10. Tysiqc v. Poland (2007) 45 EHRR 42

11. Vo v. France (2004) 40 EHRR 12

\section{LIST OF NATIONAL REGULATIONS, ACTS AND COURT DECISIONS}

1. Act on Health Measures for Exercising the Right to Free Decision on the Birth of Children (Zakon o zdravstvenim mjerama za ostvarivanje prava na slobodno odlučivanje o radanju djece), Official Gazette, No. 18/78, 31/86, 47/89 and 88/09

2. Charter of Fundamental Rights and Freedoms - Resolution of the Presidium of the Czech National Council of 16 December 1992 on the Declaration of the Charter of Fundamental Rights and Freedoms as a part of the constitutional order of the Czech Republic, [https:// www.usoud.cz/fileadmin/user_upload/ustavni_soud_www/Pravni_uprava/AJ/Listina_English_version.pdf], accessed 30. January 2019

3. Constitution of the Republic of Croatia (Ustav Republike Hrvatske), Official Gazette, No. 56/90, 135/97, 8/98, 113/00, 124/00, 41/01, 55/01, 76/10 and 5/14

4. Constitution of the Republic of Ireland, [http://www.irishstatutebook.ie/eli/cons/en\#article40], accessed 31. January 2020

5. Constitution of the Slovak Republic, [https://www.prezident.sk/upload-files/46422.pdf], accessed 30. January 2019

6. Constitution of the Socialist Federal Republic of Yugoslavia (Ustav Socijalističke Federativne Republike Jugoslavije), Official Gazette, No. 8/74

7. Constitutional Court of Hungary, Decision 64/1991 on the Regulation of Abortion, [https://hunconcourt.hu/dontes/decision-64-1991-on-the-regulation-of-abortion], Accessed 30. January 2020

8. Convention on the Protection of Human Rights and the Dignity of the Human Being with regard to the Application of Biology and Medicine: the Convention on Human Rights and Biomedicine (Konvencija o zaštiti ljudskih prava i dostojanstva ljudskog bića u pogledu primjene biologije i medicine: Konvencija o ljudskim pravima i biomedicini), Official Gazette - International Treaties, No. 13/03, 18/03 and 3/06

9. Finding of the Constitutional Court of the Slovak Republic, Ref. No. I. ÚS 12/01 of 4 December 2007, published in the Collection of Laws of the Slovak Republic under no. 14/2008, volume 8, [https://www.ustavnysud.sk/documents/10182/992296/1_07a.pdf/88e635ba-300a-4cf3-a71b-99ecfe2c8e54], accessed 30. January 2019

10. Resolution 1607 (2008) - Access to safe and legal abortion in Europe, [http://assembly. coe.int/nw/xml/XRef/Xref-XML2HTML-en.asp?fileid=17638], accessed 30. January 2019

11. Ruling of the Constitutional Court of the Republic of Croatia no. U-I-60/1991 et al. of 21 February 2017 and the dissenting opinion (Rješenje Ustavnog suda Republike Hrvatske, broj: U-I60/1991. idr. od 21. veljače 2017. i izdvojeno mišljenje), Official Gazette, No. 25/17. Retrieved from [https://sljeme.usud.hr/usud/praksaw.nsf/7114c25caa361e3ac1257f340032f11e/ c12570d30061ce54c12580d100416faf/\$FILE/U-I-60-1991\%20i\%20dr.pdf], accessed 30. January 2020, Unofficial abridged translation into English, [https://www.law.utoronto. 
ca/utfl_file/count/documents/reprohealth/croatia_2017_constitutional.pdf], accessed 30 . January 2020

12. The Fundamental Law of Hungary, English translation of the consolidated version, [http:// www.kormany.hu/download/f/3e/61000/TheFundamentalLawofHungary_20180629_ FIN.pdf], accessed 30. January 2019

\section{WEBSITE REFERENCES}

1. CESI - Centre for Education, Counselling and Research, Expert opinion to the Constitutional Court of the Republic of Croatia in reviewing the constitutionality of the Act on Health Measures for the Realization of the Right to Freely Decide on the Childbirth (Official Gazette no. 18/78), [http://stari.cesi.hr/attach/_e/expert_opinion_cc $5 . p d f]$, accessed 01. February 2019

2. Fabbrini, F., The Last Holdout: Ireland, the Right to Abortion and the European Federal Human Rights System (September 13, 2018), iCourts Working Paper Series, No. 142, 2018 [https:// ssrn.com/abstract=3249400], accessed 10. April 2020

3. Megan Clement; Bertrand Borg, How Malta's abortion taboo leaves women in despair, 11 June 2020, [https://www.theguardian.com/world/2020/jun/11/like-ireland-on-steroids-maltasabortion-taboo-leaves-women-in-despair], accessed 11. June 2020

4. Shaun Walker, Polish parliament delays decision on new abortion restrictions, 19 April 2020, [https://www.theguardian.com/world/2020/apr/16/polish-parliament-delays-decision-on-new-abortion-restrictions], accessed 20. April 2020

5. Shaun Walker, Pro-choice activists launch abortion initiative in Poland, 10 December 2019, [https://www.theguardian.com/world/2019/dec/10/pro-choice-activists-launch-abortion-initiative-in-poland], accessed 10. January 2020

6. Sheelagh McGuinness; Jane Rooney, A legal landmark in reproductive rights: The Abortion (Northern Ireland) Regulations 2020. [Web log post], 1 April 2020, [https://legalresearch. blogs.bris.ac.uk/2020/04/a-legal-landmark-in-reproductive-rights-the-abortion-northern-ireland-regulations-2020/], accessed 20. April 2020

7. The Hippocratic Oath, Translated by Michael North, National Library of Medicine, 2002, [https://www.nlm.nih.gov/hmd/greek/greek_oath.html], accessed 10. January 2020

8. Vedran Brkulj, Za legalizaciju pobačaja u Irskoj glasalo je 66.4 posto gradana, [https://www. tportal.hr/vijesti/clanak/za-legalizaciju-pobacaja-u-irskoj-glasalo-je-66-4-posto-gradana-foto-20180526], accessed 31. January 2019 